\title{
A review of biogas production from palm oil mill effluents using different configurations of bioreactors
}

\author{
Elijah Ige Ohimain* and Sylvester Chibueze Izah \\ Bioenergy and Environmental Biotechnology Research Unit, Department of Biological Sciences, \\ Faculty of Science, Niger Delta University, Wilberforce Island, Bayelsa State, Nigeria.
}

\begin{abstract}
Palm oil mill effluent (POME) is generated from the sterilization, condensation and hydrocycloning of palm oil in mills. If the effluent is discharged into the aquatic and terrestrial ecosystem without treatment, it could lead to high biological oxygen demand (BOD), chemical oxygen demand (COD) and acidic $\mathrm{pH}$ of the receiving waters. Biogas consisting mostly of methane, carbon dioxide, and to a lesser hydrogen has been produced through anaerobic treatment of this toxic effluent. The process of biogas production involves microbial synthesis involving hydrolysis, acidogenesis, acetogenesis and methanogenesis. Biogas is formed during anaerobic degradation of POME by indigenous microbial communities. This review updates the current state of art of biogas production through anaerobic digestion of POME using different configurations of reactors such as fluidized bed reactor, anaerobic filtration, up-flow anaerobic sludge blanket (UASB) reactor, anaerobic contact digestion, up-flow anaerobic sludge fixed-film (UASFF) reactor, modified anaerobic baffled bioreactor (MABB), anaerobic baffled bioreactor (ABR), continuous stirred tank reactor (CSTR), expanded granular sludge bed (EGSB) reactor, Ultrasonicated membrane anaerobic system (UMAS), Ultrasonic-assisted Membrane Anaerobic System (UAMAS), membrane anaerobic system (MAS)and upflow anaerobic sludge blanket reactor (UASBR). The factors that influences biogas yield during treatment include $\mathrm{pH}$, temperature (environmental factors), organic loading rate (OLR), hydraulic retention time (HRT), mixing rate, pressure, equilibrium, nutrient and microbial activities (Internal factors). Based on this study, UAMAS is the best configuration for methane production from POME during anaerobic treatment. Biogas from POME could contribute to energy sources of oil palm producing nations, while preventing the attendant environmental impacts associated with its disposal.
\end{abstract}

Keywords: Anaerobic digestion, biogas, palm oil mill effluents

*Corresponding author: Elijah Ige Ohimain; Tel +234 8037306 520; E-mail:eohimain@yahoo.com 


\section{Introduction}

Biomass energy resources have emerged as a credible fuel resource. Some biomass energy such as biodiesel, bioethanol etc. have been commercialized in some countries of the World. Among the notable feedstock for biomass energy is oil palm processing feedstocks, which can be used in the production of biofuels such as biogas [1, 2], bioethanol, biodiesel, bio-methanol, bio-butanol, bio-oil, briquette, bio-hydrogen and bioelectricity using different conversion technologies. Biogas is renewable with high quality fuel properties and can be utilized for various energy services such as heat, combined heat and power (electricity) and transportation fuel [3].

The use of biogas would reduce the use of fossil energy and reduce environmental impacts, including global warming and pollution, improve sanitation, reduce demand for wood and charcoal for cooking $[3,4]$. Bioconversion signifies biological transformation of waste and/or the reformation of complex organic waste into a valuable metabolite using biological processes or microorganisms (bacteria, yeast and fungi) [5]. This transformation is carried out in anaerobic digester, which uses microbes in anoxigenic conditions to stabilize the organic matters by transforming it into methane and other inorganic products [6]. Several microbial species have been known for their ability to break down organic materials present in wastes there by producing value added products [7].

Oil palm is a perennial crop cultivated extensively in the humid tropical and subtropical region [6] of West Africa where it was first cultivated [8]. But currently, Indonesia, Malaysia, Thailand, Columbia and Nigeria are the world largest producers of crude palm oil [9-11]. Oil palm is the most important species of the genus Elaeis belonging to the family Palmae [12]. However, it is often regarded as the most productive and economic oil crop in the world [12 - 19], with a hectare of oil palm crop producing 10 to 35 tonnes of fresh fruit bunch (FFB) per year [20 - 22] in comparison to 0.5-0.7 and 0.3-0.4 tonnes per hectare produced by rapeseed oil and soy bean oil, respectively [23]. Similarly, during oil palm processing, three wastes streams are generated namely solid wastes, liquid and gaseous emissions. In processing FFB, voluminous quantity of water are used [24 - 26].

Unfortunately, the physico-chemical properties of palm oil mill effluents (POME) showed that if discharged untreated into the environment, this substance could cause pollution [27]. The adverse environmental impacts associated with POME could be prevented through treatment, while tapping useful energy resources such as biogas. Both aerobic and anaerobic methods can be used to treat POME. Aerobic digester involves the use of oxygen during treatment. Aerobic digester has high microbial growth rate which could lead to lower retention time during biogas production. While anaerobic treatment process is devoid of oxygen and is characterized by slow microbial growth and far high retention time compared to aerobic processes. POME can be degraded anaerobically in an anaerobic digester to produce biogas. The anaerobic method is more effective to degrade in terms of cost and conversion into useful product. The anaerobic methods that have been widely used include fluidized bed reactor (FBR), anaerobic filtration, upflow anaerobic sludge blanket (UASB) reactor, anaerobic contact digestion, up-flow anaerobic sludge fixed-film (UASFF) reactor, modified anaerobic baffled bioreactor (MABB), anaerobic baffled bioreactor (ABR), continuous stirred tank reactor (CSTR) [28, 29], Expanded Granular Sludge Bed (EGSB) reactor, Ultrasonicated Membrane Anaerobic System (UMAS), Ultrasonicassisted Membrane Anaerobic System (UAMAS) and Membrane Anaerobic System (MAS) [1]. 
During anaerobic treatment, the organic content of POME are degraded, and this process releases methane and carbon dioxide.

The microbial synthesis pathway for the conversion of organic matter to biogas includes hydrolysis, acidogenesis, acetogenesis and methanogensis and often regarded as biomethanation process [30,31]. The decomposition of organic materials in waste water by microorganisms in the absence of air produces biogas fuel [32, 33]. This gas contributes significantly to greenhouse gas effects. The methane thus released to the atmosphere presents a special challenge to environmental protection [9]. Methane is considered to be 21 times more lethal on greenhouse effect compared to carbon dioxide emission in the atmosphere. Biogas is a colorless, relatively odorless inflammable, combustible and renewable [34, 35]. The typical composition of biogas from both estimates and actual yield from biomass is presented in Table 1. Therefore, if biogas is captured from POME, benefits could occur in two ways including; direct greenhouse gas (GHG) emission reduction and renewable energy recovery.

The utilization of biomass wastes such as POME will help reduce dependency on refined petroleum fuel products, boost electricity generation and lower environmental impact associated with oil palm processing [36]. A 30 tonne FFB per hour produces POME that could generate methane with yearly burning rate of 12.0 million litres fuel oil [37]. Additionally, biogas from the closed treatment system can be utilized as a fuel for electricity generation. Biogas burns with $60 \%$ efficiency in a conventional biogas stove [38] and it has caloric/heating value of $20 \mathrm{MJ} / \mathrm{m}^{3}$ [39], $4500-5000 \mathrm{kcal} / \mathrm{m}^{2}$ [35], while biogas from POME has energy content of $34.5 \mathrm{MJ} / \mathrm{m}^{3}$ [40].

POME contains several minerals, carbohydrates, fibres, protein, remains of oil etc and as such has environmental components. The production of biogas from POME involves microbiological processes. This typically converts POME constituents (remains of carbohydrates, protein and fatty acids) into biogas through the interaction of microbes and other factors influencing its production. These factors determine biogas production rate of from POME. Biogas production is a technological process involving the use of digesters. However, anaerobic digesters have proven to be effective for biogas production from POME. Since, its commercialization has begun, hence its sustainability also need to be studied.

Therefore, the focus of this paper is to review biogas production from POME in different configurations of anaerobic digesters. Also factors affecting the production of biogas from POME including organic loading rates (OLR), hydraulic retention time (HRT), $\mathrm{pH}$, temperature, mixing, pressure, nutrient, chemical equilibrium, microbial composition of the effluents and potential sustainability are discussed in brief.

The paper is arranged in different sections. Section 1 contained the introduction which focused on brief description of POME and biogas, their characteristics and different configurations for converting POME to biogas during treatment. The rest of the paper is organized as follows: Section 2 reviews POME generation, composition and environmental impacts. Section 3 explains the microbiological processes involved in biogas production in anaerobic digester. Section 4 focused on biogas production technology. Section 5 reviews the factors influencing biogas production. Section 6 reviews the sustainability of biogas as a renewable energy. The last section concludes by presenting best configuration for biogas production using POME as substrate. 
Table 1: Typical biogas composition

\section{POME generation, composition and environmental impacts}

Palm oil is extracted from FFB via dry or wet milling processes. The wet process of palm oil milling is the most common in most advanced oil palm producing countries [44]. POME is constantly associated with environmental burden due to the voluminous discharge of the wastewater during milling process [45]. Ahmad et al. [28] and Wu et al. [44] estimated that $5-7$ tonnes of fresh water are required for the milling of one tonne of FFB, out of these, 50 - $79 \%$ end up as POME [24, 46 - 48]

In large mills, POME is mainly generated from sterilization condensate, separator sludge (clarification) and hydrocyclone during oil palm milling processes [15, 25, 49, 50]. In small mills, POME is mostly generated from sterilization condensate and clarification but not from hydrocyclone. Raw POME consisting of complex vegetative matter is thick, brownish, colloidal slurry of water from the crushing of the palm fruit mesocarp [51]. POME is a colloidal suspension of substances of which $95-96 \%$ is water, $0.6-0.7 \%$ oil and $4-5 \%$ total solids including 2-4\% suspended solids and high concentration of organic nitrogen [25, 52, 53]. The brownish and colloidal suspension of POME contain high concentration of organic matter, high amounts of total solids, oil and grease, chemical oxygen demand (COD) and biological oxygen demand (BOD). However, it also contains considerable amounts of plants nutrient such as nitrogen, potassium, magnesium and calcium [54, 55], cadmium, copper, chromium and iron [27]. The physico-chemical properties of POME are presented in Table 2. The raw or partially treated POME has an extremely high content of degradable organic matter, which is due in part to the presence of unrecovered palm oil [26].

The high concentration of carbohydrate, protein, nitrogenous compounds, lipids and minerals found in POME [54, 56, 57] render it impossible to reuse [44] without appropriate treatment [26]. POME can cause environmental pollution due to oxygen depletion, soil pollution and other related effects [20, 26, 46, 47, 50]. The discharge of POME on aquatic ecosystem turns the water brown, smelly and slimy [47, 50], and it may kill fishes and other aquatic organisms and deny the human inhabitant of such region assess to good water for domestic uses [58]. So there is a need for mass integration approach as water management and optimization tool [59]. Untreated POME affects the health of the communities [21]. Besides, it also contaminates the land and ecosystem leading to loss of land resources and biodiversity [22].

Table 2: Physicochemical parameters of palm oil milling effluents 


\section{Microbiological processes involved in biogas production in anaerobic digester}

Anaerobic digestion is the degradation of complex organic matters in the absence of oxygen [29]. During anaerobic digestion, POME produces methane, carbon dioxide and water. The conversion processes principally involves hydrolysis, fermentation (acidogensis/acetogenesis) and methanogensis [9, 30, 51, 62, 63] (Fig. 1). The microbes commonly found in POME suspected to be involved in biogas generation are listed in Table 3 and 4.

Hydrolysis involves the conversion of POME complex substances i.e. lipids, protein and carbohydrates into monomers such as fatty acids, amino acids and sugars, respectively [9, 29, 63] by hydrolytic microorganisms and/or their enzymes. Hydrolytic pathway is high in organic waste and may become rate limiting. The size of these product play essential role in transportation in cell membrane. For instance Nayono [62] reported that small soluble products permits movement into bacteria cell membrane. During acidogenesis (Table 4), metabolic intermediaries including volatile fatty acids, alcohol, aldehydes formed are degraded into acetate, carbon dioxide and hydrogen gas [62, 63]. However acidogenesis is sometimes referred to as fermentation [62, 63]. Of these products, volatile fatty acids are mostly formed by acidogenic bacteria. In acetogenesis other products such as ethanol, lactate, propionate and butyrate are formed concurrently with the product formed during acidogenesis (acetate, carbon dioxide and hydrogen gas) [63]. The final step in biogas production is methanogenesis and two group of bacterial are involved in the process viz: acetotrophic and hydrogenotrophic [63]. Hydrogenotrophic methanogens uses hydrogen as electron acceptor for methane production, while acetotrophic methanogens uses formate as electron donor for methane and carbon dioxide reduction [31, 63]. Acetate which is from acetic acid can be directly used as a substrate by methanogenic bacteria to produce biogas (Fig 1). The degradation of the products is carried out by large diversity of facultative anaerobes through many fermentative pathways.

However, at low limited hydrogen pressure the production processes can be thermodynamically enhanced [62]. Ibrahim et al. [64] asserted that methanogenesis is the rate limiting step in anaerobic digestion. Methane gas can be captured properly using high rated anaerobic bioreactor as proposed by Ibrahim et al. [64], Borja and Banks [65]. The metabolic activities of methanogens in POME result in the production of methane gas. Typically, approximately $66 \%$ of the methane produced is formed via acetate decarboxylation, while the remaining $34 \%$ is

produced via carbon dioxide reduction mechanisms by the activities of hydrogenophilic bacteria [62]. 
Fig 1: Processes of biogas production from anaerobic treatment of POME

Table 3: Microbial species isolated from POME, which may be involved in the decomposition process.

Table 4: Microorganisms involved in microbial conversion of wastes to biogas

\section{Biogas Production Technology}

Anaerobic digestion technology has advanced within the past decades [71]. The recent anaerobic biodigester can compete favorably with aerobic systems for wastewater treatment [71]. Due to higher cell retention times of $4-10$ fold greater than those utilized in aerobic treatment processes [71], they are widely studied for the biogas production. Again, the microbial community used for biogas production (i.e. methanogens) is mostly found under anaerobic environment. Anaerobic digestion of POME typically produces biogas which is a mixture of methane and carbon dioxide in 65 and 35\% composition respectively [1, 2, 20]. The methane produced from the anaerobic digestion of POME has a good potential for power generation using gas engine. Biogas production from POME range from $20-28 \mathrm{~m}^{3}-\mathrm{CH}_{4} / \mathrm{m}^{3}$ biogas [20]. Basically, $28 \mathrm{~m}^{3}$ of biogas is produced from $1 \mathrm{~m}^{3}$ of POME [63, $72-76$ ]. About $1 \mathrm{~m}^{3}$ biogas is capable of generating about $1.8 \mathrm{kWh}$, which is equivalent to $25 \%$ power generation efficiency [20]. Ugoji [67] stated that $2.4 \mathrm{~cm}^{3}$ of biogas $/ \mathrm{m}^{3}$ of digester vol/day is produced from anaerobic digester. The power generated from POME can be transferred to the grid and consumed locally for domestic, industrial and commercial purposes. With this, the attendant environmental pollution associated with POME is prevented.

Several anaerobic digestion techniques have been employed for POME treatment, while generating energy. The major different configurations of anaerobic digestion that have been used for the treatment of POME and production of biogas including, up-flow anaerobic filtration [77], pond system, Anaerobic Filtration, Anaerobic digester, FBR, UASB, UASFF, CSTR, EGSB, UMAS, UAMAS, MAS, MABR, MABB, ABR, Suspended close anaerobic bioreactor (SCABR) and anaerobic contact digestion.

The anaerobic technologies for conversion of POME into biogas have been variously reported in literature including definition, characteristics, advantages and disadvantages. However, the merits and limitations of anaerobic and alternative POME treatment methods including membrane, evaporation and aerobic processes have been comprehensively reviewed and documented by Poh and Chong [29] and Abdulrahman et al [78]. The demerit and merit of anaerobic treatment processes have been reviewed and documented by Abdelgadir et al. [79]. Again, the advantages and disadvantages of different treatment configurations including pond 
system, anaerobic filtration, FBR, UASB, UASFF, CSTR have also been be reviewed and documented Poh and Chong [29]; Abdulrahman et al [78] Bala et al. [80]

\subsection{Pond system}

Pond system is one of the commonest treatment technology probably due to its cost effectiveness. The pond system of POME treatment has a huge potential of emitting methane gas. According to Yacob et al. [75], the ponding system is a series of 12 ponds which consisting of a cooling pond, a mixing pond, four anaerobic ponds, two facultative anaerobic ponds and four algae ponds. The detailed schematics of anaerobic open pond are found in Yacob et al. [75]. An anaerobic pond in palm oil mill in most advanced oil palm producing countries is $60 \times 29.6 \mathrm{x}$ $5.8 \mathrm{~m}$ (length $\mathrm{x}$ width $\mathrm{x}$ depth). Each pond system has a processing capacity of 54 tonnes per hour [75]. The typical retention time of anaerobic pond varies from $20-200$ days [57]. An anaerobic pond is capable of generating methane gas up to $54.4 \%$ by composition [75]. In an aerobic pond, a low emission is generated and because oxygen is fed into the digester. However, the emission of methane is greatly influenced by the method of processing and the prevailing season [29, 75].

\subsection{Anaerobic filtration}

The anaerobic filtration has been successfully employed in the treatment of POME because of the benefits ascribed to it, which includes small reactor volume with low hydraulic retention time, ability to withstand shock loadings, no solid separation/recycling and inexpensiveness of the reactor [29, 76, 77]. Typically anaerobic filtration consist of several compartment including airtight vessel and a septic tank with a temperature gauge, completely mixed digester, high rate reactor with a density highly active biomass section [78]. The schematics design of anaerobic filtration has been documented in Cavaleiro et al. [71]. This type of treatment method has recorded $63.3 \%$ of methane production by composition at an OLR of $4.5 \mathrm{~kg} \mathrm{COD} / \mathrm{m}^{3} /$ day [29].

\subsection{Modified Anaerobic Baffled Bioreactor}

MABB has proven to be efficient for POME treatment. The schematic design which have been reported by Faisal and Unno [81] have several compartments including feed tank, magnetic stirrer, peristaltic pump, water jacket, gas and effluents collection bottle, sewer, water bath etc. MABB is capable of maintaining and keeping the microbial communities especially the methanogens in close proximity especially at a long HRT, which helps the microbes to converts the volatile organic substances to methane without noticeable production of intermediate products [81]. MABB is able to produce methane gas in a range of $0.32-0.421-\mathrm{CH}_{4}$ (g-COD) ${ }^{-1}$ removal, with a corresponding methane content of $67.3-71.2 \%$ in an HRT of $3-10$ days [81]. Biogas production by MABB has the tendency of producing biogas at short HRT under high OLRs.

\subsection{Fluidized bed reactor}

A FBR is an advanced packed bed system, which permits the expansion of the bed during operation [82]. FBR is a type of anaerobic reactor device that have the capacity of carrying out several multiphase chemical reactions. FBR In addition to the already known merits of FBR, it is essential for treatment of high-strength wastewaters [78]. FBR is a treatment method employed for POME [83]. This method has the tendency of treating high-strength wastes, high up-flow 
velocity of raw POME as against anaerobic digestion method. However, the FBR has the ability to withstand high OLRs and a better methane gas production.

\subsection{Up-flow anaerobic sludge blanket}

UASB possess several features such as sludge from organic matter and biomass which settles in the reactor when the organic matter comes in contact with the sludge it will be digested by the biomass granules [29, 78, 82]. Others include influents, sludge blanket, gas separator, collection and exit sampling parts pump etc. The complete design of this configuration has been documented by Chaisri et al. [84], Amin and Vriens [85]. UASB reactor has been successfully been used for the treatment of diverse industrial effluents including those with high organic content capable of inhibiting digestion [31, 83, 86]. The suspended organic solids of POME have a high biogas potential which make the conversion technology economically feasible, which are the driving force of UASB [28]. Basically, during the use of UASB for POME treatment, over loading condition of wastewater with high volatile fatty acid content makes the process to be epileptic after about 15 days of use. However, Borja et al. [28] proposed two stage UASB for POME treatment with the intention of inhibiting the granules formed at the higher OLRs without the corresponding removal of the solid residues from the POME during treatment [29].

\subsection{Anaerobic Baffled Reactor}

ABR can treat industrial waste effluents and is economically feasible for the treatment of POME because of its simplicity and low cost [81]. ABR consists of a series of vertical baffles to force the wastewater to flow under and over them as it passes from the inlet to the outlet [88]. The detailed schematic design of ABR have been documented by Ferraz et al. [87], Liu et al. [88]. In the design of $A B R$, several modifications have been made to enhanced the efficiency in waste water treatment, such designs have been discussed in Liu et al. [88]. ABR has no mechanical component so it is not highly sophisticated. This bioreactor is meant for water soluble effluents, and is relatively stable at high OLR. The effect on HRT under steady state condition and kinetic analysis has been reported for substrate utilization and methane production [81].

\subsection{Up-flow Anaerobic Sludge Fixed-Film}

UASFF reactor is a hybrid of anaerobic filter and UASB. UASFF have two compartments including lower part which is basically UASB that aid in flocculation and development in granular sludge, while the upper section acts as fixed film reactor [89, 90]. Based on characteristics, UASFF consist of gas separator, holder, pump, settling and feed tank. The schematics of UASFF configuration have been described by Najafpour et al. [89, 90], Emadian et al. [91]. UASFF is a good technique for POME treatment [89]. Within a short HRT, UASFF have been successfully used to treat high rate anaerobic digestion of pre-settled and chemically pre-settled POME [92]. The UASFF has the potential of withstanding high loading rates more than UASB and anaerobic filter [29]. Najafpour et al. [89] reported the methane composition of $71.9 \%$ under OLR of $11.58 \mathrm{~kg} \mathrm{COD} / \mathrm{m}^{3}$ day with HRT of 3 days. The internal packing and high rate of effluent recycling are both vital to control the stability of UASFF reactor [29].

\subsection{Continuous Stirred Tank Reactor}

CSTR is sometimes refers to as closed tank digester. CSTR works at a continuous flow of reactants and products with a constant make up in the reactor including exit stream having the 
same composition as the tank [78]. The mechanical agitator of the CSTR provides more area of contact with the biomass thus enhancing gas production [78]. The design of CSTR has been documented by Irvan et al. [6]. CSTR has been used for the treatment of POME [43], to produce biogas [86]. It has mechanical agitator/blender which helps to increase the surface area for reaction [63]. CSTR has been used in Malaysia and has been functioning effectively since 1980s [93]. CSTR typically have net methane production of $62.5 \%$ by composition [63]. CSTR uses microorganisms to digest the organic substances in the waste water under anaerobic condition. During this process, the BOD of the effluent is reduced at the same time producing biogas [20].

\subsection{Anaerobic contact digestion}

Anaerobic contact digestion involves the use of digester and sedimentation tank whereby the digested effluents is left to coagulate and the effluent is recycled back into the digester [29]. Anaerobic contact digestion has been successfully been used for POME treatment, during which $63 \%$ of methane gas by composition is generated [64]. The anaerobic contact process is a type of anaerobic digester.

\subsection{Anaerobic digesters}

Anaerobic digesters are the aerobic equivalents of activated sludge process and have found application in treating diversity of effluents including sugar processing, distilleries, citric acid and yeast production, industries producing canned vegetables, pectin, starch, meat products, etc [78]. Typically anaerobic digester is cylindrical in shape with different compartments including gear motor, torque tubes, scrapper set and draft tube for mixing, hydrogen sulphide removal tank, moisture trap, gas pressure, regulator etc [36]. The design of this configuration has been documented by Puetpaiboon and Chotwattanasak [43].

\subsection{Ultrasonicated Membrane Anaerobic System, Ultrasonic-assisted Membrane Anaerobic System and membrane anaerobic system}

UMAS has two modifications including UAMAS and MAS. UAMAS have various components including cross flow ultra-filtration membrane, apparatus, a centrifugal pump, and an anaerobic reactor [95, 96]. The schematics design of UAMAS has been variously reported [94, 95]. Typically, UMAS have series of compartments including membrane reactor, membrane modules, pressure gauge, valve etc [94]. The schematics of UMAS have been documented by Abdulrahman et al. [94]. Similarly MAS consist of valve, pressure gauge, pump, sludge wastage, feeder tank, and anaerobic reactor. The design of this configuration has been reported by Abdulrahman et al. [96]. UMAS and MAS are some of the most suitable anaerobic treatment technologies of POME due to its relative small volume as compared to conventional digester [1, 94 - 96]. UMAS has the potential of removing high COD within a short period of time and thus having a high substrate removal efficiency [94-96].

\subsection{Expanded Granular Sludge Bed}

EGSB reactor has been modified from UASB. EGSB reactor comprises of three compartments including phase separator at the top, reactor body in the middle, and liquid distributor at the bottom [99]. The structural designed have been documented by Wang et al. [97] Yejian et al. [98]. EGSB has enhanced substrate-biomass contact within the treatment system by expanding 
the sludge bed and intensifying hydraulic mixing, and consequently EGSB has enhanced reactor performance and stability [98, 99]. EGSB reactor relatively stable with regard to acidity and alkalinity, hence addition of alkalis in not important for $\mathrm{pH}$ adjustment.

\subsection{Suspended Close Anaerobic Bioreactor}

SCABR typically consist of cylindrical -shaped glass vessel with total and working volume, integrated online $\mathrm{pH}$ recording system. The schematics architecture of SCABR has been reported by Wong et al. [100].

\subsection{Upflow anaerobic sludge blanket reactor}

UASBR is similar to UASB configuration with slight variation. UASBR schematics is able to generate high quality effluent that have effectively meet the stringent effluent discharge standards set out in the Environmental Quality [101]. The UASBR schematics comprises of refill pipe, POME holding tank, stirrer motor, sodium hydrogen carbonate dosing tank, $\mathrm{pH}$ and temperature indicator, baffles, water jacket, overflow pipe, liquid splitter, biogas flow meter, biogas collection port, methane gas holder, pressure controller, hot water tank, drain pump, sampling point, peristaltic pumps and control valves [101]. These compartments enhance the effective functioning of this configuration.

\subsection{Other less widely used biogas technology}

Other biogas production technologies include upflow anaerobic filter (UFAF) (which consists of gas collector pump, microbial supporting material, effluents, gas exist and the design of UFAF have been documented by Chaisri et al. [84], semi-closed digester tank (which consists of sludge recycling and appropriate feeding strategy design consisting of inlet chamber, recycling pump, settling tank, sampling port, $\mathrm{pH}$, temperature probe etc and the schematics design have been documented [102], Anaerobic hybrid reactor (whose schematic design consists of several compartment including gas counter, insulators, water tubes, sludge zones, e-circulation water inlet and outlet, feeder tank, effluent tank etc) [103], anaerobic covered lagoon (ACL), anaerobic fixed film (AFF) [84], and Upflow Anaerobic Sludge Blanket Reactor (UASBR) [101].

The methane composition (\%), HRT (days) and OLRs ( $\mathrm{kg}$ COD/m $\mathrm{m}^{3}$ day) of various anaerobic treatment methods is presented in Table 5 . The UASFF provides the best/quality performance for biogas production from POME treatment at high OLRs with low HRT as against other anaerobic treatment methods [29]. However, based on our observations, the UAMAS performs better than all other reactors due to its ability to degrade POME at higher OLR of $16 \mathrm{~kg} C O D / \mathrm{m}^{3} /$ day with a relative short HRT of 0.5 days, producing $77 \%$ of methane gas.

Table 5: Methane composition during anaerobic treatment of POME with their OLR and HRT 


\section{Factors influencing biogas production}

Bioreactor for anaerobic treatment of POME to produce biogas consisting of methane, carbon dioxide and hydrogen gas is influenced by several factors including $\mathrm{pH}$, reaction temperature, OLR, HRT, microbial activity, pressure, nutrient, chemical equilibrium, mixing of effluent among others [1, 9, 63, 94 -96]. These factors can be grouped into environmental and internal factors. However, technological challenge to improving the anaerobic digestion lies in enhancing the microbial activity together with adequate mixing to ensure uniformity of the environmental factors (i.e. temperature and $\mathrm{pH}$ ) so as to enhance the contact rate between the cells and their substrates [81].

\subsection{Environmental factors}

Environmental factors typically influence the internal working condition of the biogas technology which may affect biogas production. The major environmental factors include temperature and $\mathrm{pH}$.

\subsection{1 pH}

$\mathrm{pH}$ is a typical example of unstable parameter used in evaluating the acidity and alkalinity of water, wastewater and/ or effluents. $\mathrm{pH}$ is essential parameter that used to show strength of an effluent under anaerobic condition for biogas production. In a typical anaerobic bioreactor, the various metabolic products at each phase of biomethanation are successively transformed into their corresponding output without any major substantial accumulation of intermediate products leading to decline in $\mathrm{pH}$ [62].The decrease in $\mathrm{pH}$ is due to hindrance by the methanogenic microorganisms. Microorganisms respond to changes in internal and external $\mathrm{pH}$ by adjusting their activity and synthesis of proteins associated with proton translocation, amino acid degradation, and adaptation to acidic or alkaline conditions [106]. Nevertheless, the alkalinity of the POME is typically below the level at which optimum methane is produced. Several characteristics of the multifaceted microbial metabolism are seriously affected by differences in $\mathrm{pH}$ of the biodigester [62]. Typically, neutral $\mathrm{pH}$ favours the rate of methanogenesis during biogas production. Most anaerobic bacteria especially methanogens enhance the production of biogas at $\mathrm{pH}$ range of 6.5 to 7.5 , and peak at $\mathrm{pH}$ of 6.8 to $7.6[62,107]$. This suggests that the rate of biogas production may decline at $\mathrm{pH}$ lower than 6.5 and higher than 7.6

Typically, the higher the $\mathrm{pH}$ (tending toward neutral) and lower the alkalinity, the higher the methane composition. Fang et al. [104] reported that using UASB and EGSB design showed that deoiled POME with a $\mathrm{pH}$ and alkalinity of 4.7 and $85 \mathrm{mg} / \mathrm{l}$ respectively have a higher percentage methane (72 - 74\% for UASB and $70-73 \%$ for EGSB) than composition of $55-66 \%$ for UASB and $51-60 \%$ for EGSB under same conditions such as HRT, OLR, substrate concentration level in water. Using SCABR design Wong et al. [100] reported that methane concentration from the treatment of POME increase as $\mathrm{pH}$ increases (i.e. $\mathrm{pH}$ of 5.26, 5.36, 5.44, 5.53, 5.34 and 5.20 was $32.20,28.85,24.35,21.00$ and $18.28 \%$ respectively). However, fluctuation in the methane yield when the $\mathrm{pH}$ was increased suggesting that $\mathrm{pH}$ is not the sole factor responsible for optimal methane production from POME.

In other to control the volatile fatty acid produced, bicarbonates salts such as sodium, potassium, and calcium, calcium hydroxide (quick lime) and sodium nitrate are essential in the maintenance of the systems alkalinity. Abdulrahman et al. [94, 95] stated that sodium hydroxide could be added to maintain the $\mathrm{pH}$ of the system to a $\mathrm{pH}$ of $6.8-7.0$. Other bicarbonate alkaline that may be required by methanogens to balance $\mathrm{pH}$ during biogas production is sodium and potassium 
and lime could also be used. However, these should be carried out gradually to avoid any opposing impact on the microbial consortia [62].

\subsubsection{Temperature}

Temperature is another unstable parameter that is often consider during biogas production. Temperature is one parameter that basically designates the efficiency of biogas production probably because it varies with the rates of hydrolysis and methanogenesis $[1,62]$. Temperature also impacts on the metabolic events of the microbial density, gas transfer rates and settling features and condition of the remains of solid materials found in the substrate [62, 107]. POME generated in palm oil mills is usually discharged at a temperature of about $80-90^{\circ} \mathrm{C}[5,108]$. This temperature range makes both mesophilic and thermophilic microbes to function effectively during treatment [29]. The treatment of POME at a high temperature (thermophilic $\left(55^{\circ} \mathrm{C}\right.$ ) generates high gas when compared to mesophilic $\left(37^{\circ} \mathrm{C}\right)$ temperature. Mesophilic bacteria are hypothetically more vigorous and forceful and can withstand high variation in the environmental conditions such as temperature [62]. For instance, Yu et al. [109] reported that biogas is produced at high temperature of $55^{\circ} \mathrm{C}$ compare to temperature of $37^{\circ} \mathrm{C}$. In Malaysia, Yeoh [110] reported that biogas and methane yield at $35^{\circ} \mathrm{C}$ to be $0.78 \mathrm{~m}^{3} \mathrm{~kg}^{-1}$ - BOD and $0.47 \mathrm{~m}^{3} \mathrm{~kg}^{-1}$ BOD respectively whereas at $55^{\circ} \mathrm{C}$ the biogas and methane yield were $1.41 \mathrm{~m}^{3} \mathrm{~kg}^{-1}$ - BOD and $0.92 \mathrm{~m}^{3} \mathrm{~kg}^{-1}$ - BOD respectively. At cold climates, poor insulated digesters are vulnerable to temperature variations, which may be valuable if the digester is run in the mesophilic temperature range. Thermophilic process offers higher rate of substrate degradation, biogas production and specific formation rate [109]. During biogas production at thermophilic temperature, fluctuation influence may affect the stability of the system. But, this problem can be overcome by keeping the microbial community in close proximity [29]. Temperature typically plays a vital role in OLRs and HRT during biogas production. Yilmaz et al. [111] and Kim et al. [112] asserted that temperature withstand high OLRs and short HRT in the production of more biogas. Therefore thermophilic condition which enhances the production of biogas more could be maintained by using appropriate insulation technology.

\subsection{Internal factors}

Another condition that affects biogas production in anaerobic configuration is internal factors. These factors include OLR, nutrient composition, hydraulic retention time, microbial activity including diversity and density, pressure, inhibitory materials, chemical equilibrium and mixing rate.

\subsubsection{Nutrients}

Biogas is produced via microbial breakdown of POME. These microbes requires nutrient to function effectively. Several micro (trace) and macro element such as potassium, sodium, magnesium, calcium, iron, cadmium, chromium, nitrogen are needed, even though some of the minerals found in POME could be toxic to the biogas producing microorganisms. These toxic substances are produced from leaching processing equipment, and can decrease the rate at which methane is produced. In Nigeria, such rate reductions are common because oil palm industry is basically handled by smallholder who uses rudimentary equipment during processing. During processing, rainfall could increase the volume of POME, which may result to nutrient level being 
lowered as well as inhibitory materials. Rainfall during processing can also contribute to low methane yield at high HRT.

\subsubsection{Hydraulic retention time and organic loading rate}

HRT is typically used to determine time that a certain substrate exist in a bioreactor. The OLR is defined as the amount of organic matter that must be treated by a certain volume of anaerobic digester in a certain period of time [62]. In anaerobic biodigester with constant mixing, the substances in the bioreactor have a comparative even retention time [62]. System catastrophe usually occurs due to short HRT. This is dictated by the rate of growth of important microbial community of the bioreactor $[62,113]$, even though this process leads to a high yield of methane. Najafpour et al. [89] reported a HRT of 3 days with $71.9 \%$ methane gas production rate. HRT enhances metabolic shift in concurrence with extended fermentation time, nature of effluent, $\mathrm{pH}$ and OLR [114]. Furthermore, short HRT yields a higher biogas production rate, but less efficient degradation of organic matter. Atif et al. [115] and Vijayaraghavan and Ahmad [116] reported an average biogas generation of $0.42 \mathrm{~L} / \mathrm{g}$ COD destroyed, with hydrogen content of $57 \%$ at 7 day HRT using microflora isolated from the sludge of an anaerobic pond treatment of POME on the effects of hydrogen production from POME studies.

The OLR is frequently shows the relationship with the HRT value. In substrate with fairly stable organic constituents, high OLR is obtained at short HRT [62]. Fang et al. [104] reported that overloading in EGSB could lead to poor biomass settlement leading to wash off by the effluents. Also when the OLR increases, methane production rate is intensified. But excess OLR due organic over load often results to acidity of the medium which is detrimental to methanogens [104, 117], which could lead to reduction in methane composition [106]. Under separate reactors, Fang et al. [104] reported that overloading in EGSB could lead to poor biomass settlement. However, in this study (Table 5) showed that the OLR varies even at constant HRT. During treatment, biogas production is enhanced with OLR until the methanogens could not convert the acetates produced to methane [29]. Again, this study has shown that high OLR produces high methane gas as compared to low OLR with relative short HRT.

The optimization of HRT and OLR depend mainly on the type of configuration. Some treatment technology generates higher methane composition at lower OLR at higher HRT e.g. anaerobic digester, MAS, UMAS, SCABR, while few others produces high methane composition at higher OLR at lower HRT e.g. UAMAS (Table 5). Hence, configurations with lower HRT and OLR should be studied for optimization for biogas production from POME during anaerobic treatment.

\subsubsection{Microbial Population and Activities}

The role of microbes in biogas formation is often taken for granted. Researchers erroneously believe that once anaerobic conditions are provided, suitable methane producing biota became established. Biogas formation is a complex process involving different processes such as hydrolysis, acidogensis, acetogenesis and methanogensis involving different types of microorganisms. Ohimain et al. [55, 66] and Ugoji [67] isolated microorganisms capable of catalyzing the four basic steps that could lead to biogas production from POME. Work on the microbial content of POME is limited. However among the few available include Ohimain et al. $[55,66]$, that reported the microbial content to be in the range of $10^{5}$ to $10^{6} \mathrm{cfu} / \mathrm{ml}$. Izah and Ohimain [13], Okechalu et al. [17] isolated some groups of microorganisms from crude palm oil that have not been reported in POME before and these species include Proteus spp., 
Enterobacter spp. Because these microbes are found in crude palm oil, this may be the reason that these species are also found in POME. Proteus are hydrolytic bacteria, which could convert protein to amino acids and peptide.

The role of methanogenes in biogas production is a major factor in anaerobic treatment technology just as the other factors that influences biogas yield. In other to optimize the microbial constituents, more methanogenes could be introduced into the medium. Due to less methanogenes reported in POME as compared to other microbes that play essential roles in hydrolysis, acidogensis and acetatogenesis.

\subsubsection{Presence of inhibitory materials}

Presence of inhibitory materials during biogas production could be noxious to the medium and this could lead to reduction in biogas production rate and without significant decrease in chemical oxygen. It could also leads to inability of the microbial consortia to acclimatize. Acclimatization is the capacity of microbes to reposition or reorganize their metabolic tendencies to surpass the metabolic shock that may be generated by the inhibitory materials when the levels of these substances are gradually enhanced within the environment [1, 62]. Light metal ions, heavy metals and organic compound are substances that are capable of causing inhibition during anaerobic treatment of POME for biogas production.

The light metal ions that are found in POME include sodium, potassium, calcium, and magnesium etc. These ions may affect the rate of biogas production. For instance, adequate ions levels are crucial for the stimulation of microbial growth, while high level could slow down growth and promotes inhibition [62]. Salt that frequently occurred in the effluent are cations and anions. Although cations salt in solution are associated with anions. Again, cation which associated anion in biogas bioreactor is harmful to the system. Potassium has been reported to occur in large concentration in POME [20].

In addition, heavy metals in trace concentration in POME could enhance the growth of microflora. Though, heavy metals are not easily biodegradable and can accumulate to potentially toxic levels in the bioreactor. The toxic effect of heavy metals is associated to their capacity to deactivate a wide spectrum of enzyme function and structures [118 cited in 62].

Also, organic material of POME possesses inhibitory potential during anaerobic digestion for biogas production. Exposure time, temperature of the POME and acclimatization of the organic materials could influences biogas production from POME. However, POME have been variously reported to contain high levels of organic materials particularly oil and grease. Typically materials such as oil in the POME could reduce methane yield. For instance, Fang et al. [104] reported a higher methane yield in deoiled POME than oily POME using UASB and EGSB treatment technology.

Inhibitory materials such as oil and grease could be avoided by deoiling the POME. Study by Fang et al. [104] showed that deoiled POME enhances methane composition at lower OLR using UASB and EGSB treatment technology than oily POME (Table 5). Nutrients (light ions) are required by microbes, hence increasing the microbial density of the medium could aid in the reduction of inhibition due to nutrient during treatment, while enhancing methane yield due to the activities of microbes that utilizes the POME nutrients.

\subsubsection{Pressure}


High pressure produced in the biogas digester during anaerobic treatment could affect the production rate of methane. Barophilic microorganisms may be present in POME, although none have been reported. At high pressure, the microbial and chemical equilibrium of the system could be challenging if the methane produced is not tapped instantly into use. Low methanogenic bacteria population in POME could result to low yield of methane. The overall pressure that occurs during biogas production could adversely affect bacteria if the weight of the gases outside the reactor is greater than the force inside the system. Negative pressure will pull air into the reactor and the mixture (biogas and air) may explode. When such an explosion occurs, the oxygen in the air destroyed the microbial properties of the POME and methane production ceases. This could be adverted by tapping the methane as its being produced.

\subsubsection{Mixing condition}

Mixing aids in the dilution of inhibitory substances and stabilization of enabling environmental condition for maximum biogas yield. During anaerobic treatment of POME, if the $\mathrm{pH}$ or temperature of the same substrate in reactor varies due to volume, the overall gas production will be affected. So therefore, mixing is essential for optimal biogas yield, although it has to be moderate amount of mixing because low and high mixing affects the methanogens found in the POME.

\subsubsection{Chemical equilibrium}

At least three processes influence the chemical equilibrium of biogas production. These include hydrolysis involving the breakdown of complex polymers of POME into monomers [119], the conversion of volatile fatty acids formed into acetate, hydrogen gas and carbon dioxide [64] and the utilization of the gas produced. The hydrolysis process is considered to be the driving force of biogas production from POME because it requires high energy and the process is slow. Volatile fatty acid is converted to methane through the activities of acetogenic and acetoclastic methanogens found in POME. This conversion process can only be thermodynamically favored if the partial hydrogen pressure is kept low. Ibrahim et al. [64] reported that methanogenesis is the rate limiting step in anaerobic digestion. Methane gas can be captured properly using high rated anaerobic bioreactor. The utilization of the gas can shift the equilibrium to the right i.e. in favor of the product.

\section{Sustainability of biogas as a renewable energy}

Biogas is one of the renewable energy produced from anaerobic digestion technology. Biogas can gain triple benefits in the reduction of organic pollutants for environmental protection, resources conservation, and generation of high quality renewable fuel [83]. POME typically produces two form of gas; biogas and bio-hydrogen gas. Biogas production is not challenged by raw material because oil palm milling is carried out continually in oil palm producing countries. Biogas can be used as a source of heat by direct combustion. The system reduces pollutants and also produces biogas that mills utilizes as fuel to produce electricity using the internal combustion engines. In Thailand, biogas is used in form of thermal energy (heat) and electricity. The existing utilization of biogas was 224 ktoe for thermal energy and 46 MW for electricity in 2005 [120, 121]. Biogas anaerobic digester has been able to produce electricity using $500 \mathrm{~kW}$ 
gas engines [43]. The efficiency of the gas engine that used $65 \% \mathrm{CH}_{4}$ of biogas was calculated to be $35 \%$ efficient. The Malaysia Government has recommended POME treatment at thermophilic temperature so as to generate biogas at a range of about 2250 million $\mathrm{kWh}$ of electricity which is capable of contributing about 4\% of the national electricity demand of Malaysia in 1999 [29]. Also, the Bunge Guatemala POME project estimated 22,500 $\mathrm{m}^{3} /$ day biogas production and electricity generation of $2 \mathrm{MW}$ [122]. Furthermore, the recovery and utilization of methane contributes to significant GHG emission reduction [43].

Biohydrogen production attracts attention of researchers, as it is less energy intensive and can be coupled with wastewater treatment processes using dark-and photo-fermentation techniques [6]. Thus, biohydrogen is characterized with a high energy yield of $122 \mathrm{MJ} / \mathrm{kg}$ which is 2.75 times higher than the hydrocarbon fuels and the only end-product is water [123]. These characteristics make it a promising alternative fuel. The recent biological approach to producing hydrogen is to convert agro-industrial residues into hydrogen-rich gas through anaerobic processes by microbial action. Researchers have established many means of harnessing hydrogen from POME [6]. Therefore, sustainable production of biohydrogen from POME could help in reducing the energy-linked environmental impacts of global warming [29] due to anthropogenic carbon emissions and mobile source emissions such as carbon monoxide, nitrogen oxides, sulphur oxides, non-methane hydrocarbons, and particulates [6].

\section{Conclusion}

With the increase in cost of conventional energy resources and concern over climate change, there is a growing need for energy resources that are sustainable and can provide base-load electrical generating capacity. The world energy supply has diminished over the past years, even when global population has increased. Hence, there is intense search for energy from renewable resources. POME has emerged as one of the fastest growing biogas resources. POME is generated in palm oil mill during the processing of FFB of oil palm to palm oil. Biogas is produced through anaerobic treatment of the effluent. Though, the production of biogas from POME is still at the infant stage, advanced oil palm producing countries like Malaysia and Thailand are currently tapping the resources for heat and power generation. Among the several configuration reviewed UAMAS appears to be superior due to the fact that high methane composition is produced at lower HRT and OLR. Also the study found that biogas yield is influenced by several factors depending on the configurations. However, POME discharged into the environment without treatment can lead to environmental pollution.

\section{Acknowledgement}

The authors wish to thank Dr. Beth Middleton of USGS for proofreading the manuscript. The authors also wish to thank the three anonymous reviewers and Editor-in-Chief for the valuable comments and suggestions.

\section{References}

[1] Ohimain EI, Izah SC. Potential of Biogas Production from Palm Oil Mills' Effluent in Nigeria. Sky Journal of Soil Sciences and Environmental Management 2014; 3(5): 50 - 8. 
[2] Ohimain EI, Izah SC. Estimation of potential electrical energy and currency equivalent from un-tapped palm oil mill effluents in Nigeria. International Journal of Farming and Allied Science 2014; 3 (8): 855-62.

[3] Mshandete AM, Parawira W. Biogas technology research in selected sub-Saharan African countries - A review. African Journal of Biotechnology 2009; 8 (2): 116-25

[4] Paepatung N, Nopharatana A, Songkasiri W. Bio-Methane Potential of Biological Solid Materials and Agricultural Wastes. Asian Journal on Energy and Environment2009; 10(01): 1927.

[5] Salihu A, Alam Z. Palm oil mill effluent: a waste or a raw material? Journal of Applied Sciences Research 2012; 8(1): 466-73.

[6] Irvan (no initial), Trisakti B, Wongistani V, Tomiuchi Y. Methane Emission from Digestion of Palm Oil Mill Effluent (POME) in a Thermophilic Anaerobic Reactor. International Journal of Science and Engineering 2012; 3(1):32-5.

[7] Alam MZ, Kabbashi NA, Razak AA. Liquid state bioconversion of domestic wastewater sludge for bioethanol production In: Ibrahim FNA, Abu Osman J, Usman Kadri NA. (Eds.). Biomed 06, IFMBE Proceedings 2007; 15: 479-82.

[8] Poku K. Small-scale palm oil processing in Africa. Rome, Italy: Agriculture Services Bulletin 148. Food and Agricultural Organization of the United Nations. 2002.

[9] Ohimain EI, Izah SC. Possible contributions of palm oil mill effluents to greenhouse gas emissions in Nigeria. British Journal of Applied Science and Technology 2014; 4(33): 47054720.

[10] Izah SC, Ohimain EI. Microbiological quality of palm oil used in Nigeria: Health impacts perspective. Point Journal of Botany and Microbiology Research 2016; 2(1): 037 - 045.

[11]Izah SC, Ohimain EE, Angaye TCN. Potential thermal energy from palm oil processing solid wastes in Nigeria: mills consumption and surplus quantification. British Journal of Renewable Energy 2016; 1(1): 38 - 44.

[12] Rupani PF, Singh RP, Ibrahim H, Esa N. Review of Current palm oil mill effluent (POME) treatment methods: Vermicomposting as a sustainable practice. World Applied Sciences Journal 2010; 11 (1): 70-8I.

[13] Izah SC, Ohimain EI. Microbiological quality of crude palm oil produced by smallholder processors in the Niger Delta, Nigeria. Journal of Microbiology and Biotechnology Research 2013; 3(2): 30 - 6.

[14] Akangbe JA, Adesiji GB, Fakayode SB, Aderibigbe YO. Towards palm oil self-sufficiency in Nigeria: constraints and training needs nexus of palm oil extractors. J Hum Ecol 2011; 33(2): $139-45$.

[15] Sumathi S, Chai SP, Mohamed AR. Utilization of oil palm as a source of renewable energy in Malaysia. Renewable and Sustainable Energy Reviews 2008; 12: 2404 -21.

[16] Ugbah MM, Nwawe CN. Trends in oil palm production in Nigeria. Journal of Food, Agriculture and Environment 2008; 6(1): 119-22.

[17] Okechalu JN, Dashen MM, Lar PM, Okechalu B, Gushop T. Microbiological quality and chemical characteristics of palm oil sold within Jos Metropolis, Plateau State, Nigeria. Journal of Microbiology and Biotechnology Research 2011; 1(2): 107-12.

[18] Ngando EGF, Mpondo MEA, Dikotto EEL, Koona P. Assessment of the quality of crude palm oil from smallholders in Cameroon. Journal of Stored Products and Postharvest Research. 2011; 2(3): 52-8. 
[19] Dimelu MU, Anyaiwe V. Priorities of smallholder oil palm producers in Ika Local Government Area of Delta State: implication for agricultural extension service in Nigeria.World Journal of Agricultural Sciences 2011; 7 (2): 117-23.

[20] Sridhar MKC, AdeOluwa OO. Palm oil industry residue. Biotechnology for agro-industrial residues utilisation. Nigam, P.S and Pandey, A. (eds.). Springer Science. 2009. Pp 341 - 55.

[21] Singh RP, Ibrahim MH, Norizan E, Iliyana MS. Composting of waste from palm oil mill: a sustainable waste management practice. Rev. Environ. Sci. Biotechnol.2010; 9: 331-44.

[22] Singh RP, Embrandiri A, Ibrahim MH, Esa N. Management of biomass residues generated from oil mill: vermicomposting a sustainable option. Resour. Conserv. Recy. 2011; 55: 423-34.

[23] Århem K. Environmental consequences of the palm oil industry in Malaysia. Bachelor's degree thesis in Physical Geography and Ecosystems Analysis, Department of Earth and Ecosystem Sciences. Lund University. 2011.

[24] Ohimain EI, Izah SC. Water minimization and optimization by small-scale palm oil mill in Niger Delta, Nigeria. Journal of Water Research 2013; In press.

[25] Ma AN. Environmental management for the oil palm industry. Palm Oil Dev 2000; 30:1-10. [26] Ahmad AL, Ismail S, Bhatia S. Water recycling from palm oil mill effluent (POME) using membrane technology. Desalination 2003; 157: 87-95.

[27] Ohimain EI, Seiyaboh EI, Izah SC, Oghenegueke VE, Perewarebo TG. Some selected physico-chemical and heavy metal properties of palm oil mill effluents. Greener Journal of Physical Sciences 2012; 2(4): 131 - 7.

[28] Borja R, Banks CJ, Sanchez E. anaerobic treatment of palm oil mill effluent in a two-stage up-flow anaerobic sludege blanket (UASB) system. Journal of Biotechnology 1996; 45: 125 35.

[29] Poh PE, Chong MF. Development of anaerobic digestion methods for palm oil mill effluent (POME) treatment. Bioresource Technology 2009; 100: 1 - 9.

[30] Trisakti B, Manalu V, Taslim I, Turmuzi M. Acidogenesis of palm oil mill effluent to produce biogas: effect of hydraulic retention time and ph. Procedia-Social and Behavioral Sciences 2015; 195: 2466-2474.

[31] Demirel B, Scherer P. The roles of acetotrophic and hydrogenotrophic methanogens during anaerobic conversion of biomass to methane: a review. Rev Environ Sci Biotechnol 2008; 7: 173 -190 .

[32] Ilaboya IR, Asekhame FF, Ezugwu MO, Erameh AA, Omofuma FE. Studies on biogas generation from agricultural waste; analysis of the effects of alkaline on gas generation. World Applied Sciences Journal 2010; 9 (5): 537-45.

[33] Akinbami J-FK, Ilori MO, Oyebisi TO, Akinwumi IO, Adeoti O. Biogas energy use in Nigeria: current status, future prospects and policy implications. Renewable and Sustainable Energy Reviews 2001;597-612

[34] Igoni AH, Abowei MFN, Ayotamuno MJ, Eze CI. Effect of total solids concentration of municipal solid waste in anaerobic batch digestion on the biogas produced. Journal of Food, Agriculture and Environment2007; 5(2): 333-7.

[35] Igoni AH, Abowei MFN, Ayotamuno MJ, Eze CI. Comparative evaluation of batch and continuous anaerobic digesters in biogas production from municipal solid waste using mathematical models. Agricultural Engineering International: the CIGR Ejournal 2008; 10: 1 12.

[36] Chotwattanasak J, Puetpaiboon U. Full scale anaerobic digester for treating palm oil mill wastewater. Journal of Sustainable Energy and Environment 2011; 2: 133 - 6. 
[37] EnergyWise. Optimising the Utilisation of Renewable Energy Resources in the Oil Palm Industry. 2011. http//: rank.com.myenergywise/?p=17. Accessed 18 November 2012.

[38] Food and Agricultural Organisation (FAO). A system approach to biogas technology. 2007; http://www.fao.org/sd/EGdirect/EGre0022.htm. Accessed December 20, 2012.

[39] Eze JI, Ojike O.Anaerobic production of biogas from maize wastes. International Journal of the Physical Sciences 2012; 7(6): 982 - 7.

[40] Foo KY, Hameed BH. Insight into the applications of palm oil mill effluent: A renewable utilization of the industrial agriculture waste. Renewable and Sustainable Energy Review, 2010; 14: $1445-52$.

[41] Madu C, Sodeinde OA. Relevance of biomass in the sustainable energy development in Nigeria. Proceedings of the National Engineering Conference and Annual General Meeting of the Nigerian Society of Engineers. 2001; Pp 220-7.

[42] Jewell W, Cummings R, Richards B. Methane fermentation of energy crops: Maximum conversion kinetics and in situ biogas purification. Biomass Bioenergy 1993; 5(3-4): 261-78.

[43] Puetpaiboon U, Chotwattanasak J. Anaerobic treatment of palm oil mill wastewater under mesophilic condition. Proceeding of the $10^{\text {th }}$ World Congress on Anaerobic Digestion 2004, Montreal, Canada, August 29-September 2, 2004.

[44] Wu TY, Mohammed AW, Jahim JM, Anuar N. A holistic approach to managing palm oil mill effluent (POME): Biotechnological advances in the sustainable reuse of POME. Biotechnology Advances 2009; 27: 40 - 52.

[45] Ismali I, Hassan MA, Rahman NAA, Soon CS. Thermophilic biohydrogen production from palm oil mill effluent (POME) using suspended mixed culture. Biomass and Bioenergy 2010; 34: $42-7$.

[46] Awotoye OO, Dada AC, Arawomo GAO. Impact of palm oil processing effluent discharging on the quality of receiving soil and rivers in South Western Nigeria, Journal of Applied Sciences Research 2011; 7(2): 111 - 8.

[47] Okwute LO, Isu NR.The environmental impact of palm oil mill effluent (POME) on some physico-chemical parameters and total aerobic bioload of soil at a dump site in Anyigba, Kogi State, Nigeria. African Journal of Agricultural Research 2007; 2 (12): 656-62.

[48] Chavalparit O, Rulkens WH, Mol APJ. Khaodhair S. Options for environmental sustainability of the crude palm oil industry in Thailand through enhancement of industrial ecosystem. Environmental, Development and Sustainability 2006;8: 271-87.

[49] Er AC, Nor Abd. RM, Rostam K. Palm oil milling wastes and sustainable development. American Journal of Applied Sciences 2011; 8(5): 436-40.

[50] Khalid R, Wan Mustafa WA. External benefits of environmental regulation: Resource recovery and the utilisation of effluents. The Environmentalist 1992; 12: 277-85.

[51] Bek-Nielsen C, Singh G, Toh TS. Bioremediation of palm oil mill effluent. In: Proceedings Porim International Palm Oil Congress 16th February 1999, Kuala Lumpur, Malaysia.

[52] Onyia CO, Uyub AM, Akunna JC, Norulaini NA, Omar AKM. Increasing the fertilizer value of palm oil mill sludge: bioaugumentation in nitrification. Water Science and Technology 2001; 44(10): 157-62.

[53] Ahmad AL, Sumathi S, Hameed BH. Adsorption of residue oil from palm oil mill effluent using powder and flake chitosan: equilibrium and kinetic studies. Water Res. 2005; 39: 2483 94. 
[54] Habib MAB, Yusoff SM, Phang KJ, Mohamed S. Nutritional values of chironomid larvae grown in palm oil mill effluent and algalculture. Aquaculture 1997; 158: 95-105.

[55] Ohimain EI, Izah SC, Jenakumo N. Physicochemical and microbial screening of palm oil mill effluents for amylase production. Greener Journal of Biological Sciences 2013;3(8): 314 25.

[56] Ngan MA, Zajima Y, Asahi M, Junit H. A novel treatment processes for palm oil mill effluent. PROIM Technology 1996.

[57] Chan KS, Chooi CF. Ponding system for palm oil mill effluent treatment. In Proc Regional Workshop on Plam Oil mill Effluent Technology and effluent Treatment PORIM, Malaysia 1982; pp. 185-92.

[58] Ezemonye LIN, Ogeleka DF, Okieimen FE. Lethal toxicity of industrial chemicals to early life stages of Tilapia guineensis. Journal of Hazardous Materials 2008; 157(1): 64-8.

[59] Chungsiriporn J, Prasertsan S, Bunyakan C. Toward cleaner production of palm oil mills: Part 2 minimization of water consumption and process optimization. Asian Journal on Energy and Environment 2006; 7(1): 246-57.

[60] Wood BJ, Pillia KR, Rajaratnam JA. Palm oil mill effluent disposal on land. Agricultural Wastes1979; 1: 103-27.

[61] Okogbenin OB, Anisiobi GE, Okogbenin EA, Okunwaye T and Ojieabu A. Microbiological assessment and physiochemical parameters of palm oil mill effluent collected in a local mill in Ovia North East area of Edo State, Nigeria. Herald Journal of Microbiology and Biotechnology 2014; 1(1): 001 - 009

[62] Nayono SE. Anaerobic digestion of organic wastes for energy. Scientific Publishing. ISBN 978-3-86644-464-5. 2010; pp. 7 - 20.

[63] Lam MK and Lee KT. Renewable and sustainable bioenergies production from palm oil mill effluent (POME): Win-win strategies toward better environmental protection. Biotechnology Advances 2011; 29: 124-141.

[64] Ibrahim A, Yeoh BG, Cheah SC, Ma AN, Ahmad S, Chew TY, Raj R, Wahid MJA. Thermophilic anaerobic contact digestion of palm oil mill effluent. Water Science and Technology 1984; 17:155-65.

[65] Borja R, Banks CJ. Anaerobic digestion of palm oil mill effluent using an up-flow anaerobic sludge blanket reactor. Biomass and Bioenergy 1994; 6: 381-9.

[66] Ohimain EI, Daokoru-Olukole C, Izah SC, Eke RA, Okonkwo AC. Microbiology of palm oil mill effluents. Journal of Microbiology and Biotechnology Research 2012; 2(6):852 - 7.

[67] Ugoji EO. Anaerobic digestion of palm oil mill effluent and its utilization as fertilizer for environmental protection. Renewable Energy 1997; 10(2-3): 291- 4.

[68] Wakil SM, Fasiku, SA, Adelabu AB, Onilude AA. Production of bioethanol from palm oil mill effluent using starter cultures. New York Science Journal 2013; 6(3):77-85.

[69] Wakil SM, Fasiku, SA, Adelabu AB, Onilude AA. Production of bioethanol from spontaneous fermentation of palm oil mill effluent (POME). Researcher 2013; 5 (2): 28-35.

[70] Stronach SM, Rudd T, Lester JN. Anaerobic digestion processes in wastewater treatment. Berlin: Springer, 1986.

[71] Cavaleiro AJ, Alves MM, Mota M. Microbial and operational response of an anaerobic fixed bed digester to oleic acid overloads. Process Biochem. 2001; 37: 387-94. 
[72] Puah CW, Choo WM, Ong SH. Production of palm oil with methane avoidance at palm oil mill: a case study of cradle-to-gate life cycle assessment. American Journal of Applied Sciences 2013; 10 (11): 1351-5.

[73] Vijaya S, Ma AN, Choo YM. Capturing biogas: a means to reduce green house gas emissions for the production of crude palm oil. American Journal of Geoscience 2010; 1 (1): 1-6.

[74] Yacob S, Hassan MA, Shirai Y, Wakisaka M, Subash S. Baseline study of methane emission from open digesting tanks of palm oil mill effluent treatment. Chemosphere 2005; 59:1575-81.

[75] Yacob S, Hassan MA, Shirai Y, Wakisaka M, Subash S. Baseline study of methane emission from anaerobic ponds of palm oil mill effluent treatment. Science for Total Environment 2006; 366: 187-96

[76] Quah SK, Gillies D (1984). Practical experience in production and use of biogas. In: Proceeding of National Workshop on Oil Palm By-products. Palm Oil Research Institute of Malaysia, Kuala Lumpur, 119-126.

[77] Borja R, Banks CJ. Treatment of palm oil mill effluent by up-flow anaerobic filtration. Journal of Chemical Technology and Biotechnology 1994; 61:103-9.

[78] Abdurahman NH, Roslia YM, Azhari NH. The Performance Evaluation of Anaerobic Methods for Palm Oil Mill Effluent (POME) Treatment: A Review. 2013; http://dx.doi.org/10.5772/54331.

[79] Abdelgadir A, Chen X, Liu J, Xie X, Zhang J, Zhang K, Wang H, Liu N. Characteristics, Process Parameters, and Inner Components of Anaerobic Bioreactors. BioMed Research International 2014; http://dx.doi.org/10.1155/2014/8415731

[80] Bala JD, Lalung J, Ismail N. Palm Oil Mill Effluent (POME) Treatment “Microbial Communities in an Anaerobic Digester": A Review. International Journal of Scientific and Research Publications 2014; 4(6): 1 -24.

[81] Faisal M, Unno H. kinetic analysis of palm oil mill wastewater treatment by a modified anaerobic baffled reactor. Biochemical Engineering Journal 2001; 9: 25 - 31.

[82] Alade AO, Jameel AT, Muyibi SA, Karim MA, Alam MZ. Application of semifluidized bed bioreactor as novel bioreactor system for the treatment of palm oil mill effluent (POME). African Journal of Biotechnology 2011; 10(81): 18642-8.

[83] Borja R, Banks CJ. Response of an anaerobic filter and an anaerobic fluidized bed reactor treating ice-cream wastewater to organic hydraulic, temperature and $\mathrm{pH}$ shocks. Journal of Biotechnology 1995; 39:251-9.

[84] Chaisri R., Boonsawang P, Prasertsan P, Chaiprapat S. Effect of organic loading rate on methane and volatile fatty acids productions from anaerobic treatment of palm oil mill effluent in UASB and UFAF reactors Songklanakarin Journal of Science and Technology 2007; 29 (Suppl 2): 311-23. 
[85] Amin GA and Vriens L. Optimization of up-flow anaerobic sludge blanket reactor for treatment of composite fermentation and distillation wastewater. African Journal of Biotechnology 2014; 13(10): 1136-42.

[86] Chaiprasert P. Biogas production from agricultural wastes in Thailand. Journal of Sustainable Energy and Environment Special Issue 2011; 63-5

[87] Ferraz FM, Bruni AT, Del Bianchi VL. Performance of an Anaerobic Baffled Reactor (ABR) in treatment of cassava wastewater. Brazilian Journal of Microbiology 2009; 40:48-53.

[88] Liu R, Tian Q and Chen J. The developments of anaerobic baffled reactor for wastewater treatment: A review. African Journal of Biotechnology 2010; 9(11): 1535-42.

[89] Najafpour GD, Zinatizadeh AAL, Mohammed AR, Hasnain IM, Nasrollahzadeh H. Highrate anaerobic digestion of palm oil mill effluent in an upflow anaerobic sludge-fixed film bioreactor. Process Biochemistry 2006; 41:370-9.

[90] Najafpour GD, Hashemiyeh BA, Asadi M, Ghasemi MB. Biological Treatment of Dairy Wastewater in an Upflow Anaerobic Sludge-Fixed Film Bioreactor. American-Eurasian Journal of Agriculture and Environmental Science 2008; 4 (2): 251-7.

[91] Emadian SM, Rahimnejad M, Hosseini M, Khoshandam B. Investigation of up-flow anaerobic sludge fixed film (UASFF) reactor for treating low strength bilge water of Caspian seaship. Journal of Environmental Health Science and Engineering, 2015; 13: 2. DOI 0.1186/s40201-015-0181-3.

[92] Zinatizadeh AAL, Mohamed AR, Mashitah MD, Abdullah AZ, Isa MH. Optimization of pre-treated palm oil mill effluent digestion in an up-flow anaerobic sludge fixed film bioreactor: A comparative study. Biochemical Engineering Journal 2007; 35: 226-37

[93] Tong SL Jaafar AB. POME Biogas capture, upgrading and utilization as fertilization. Palm Oil Engineering Bulletin 2006; 78:11-7.

[94] Abdulrahman NH, Roslia YM Azhari NH (2013).Ultrasonic membrane anaerobic system (UMAS) for wastewater treatment. International Conference on Environmental Protection and Renewable Energy. Sep 7, 2013 Pattaya, 161 - 168.

[95] Abdulrahman NH, Azhari NH. Performance of Ultrasonic Membrane Anaerobic System (UMAS) in Membrane Fouling Control. International Journal of Engineering Science and Innovative Technology 2013; 2(6): 480 - 91

[96] Abdulrahman NH, Rosli YM, Azhari NH, SF (2011). Biomethanation of Palm Oil Mill Effluent (POME) by Membrane Anaerobic System (MAS) using POME as a Substrate, World Academy of Science, Engineering and Technology 2011; 51: 419 - 24.

[97] Wang J, Mahmood Q, Qiu J-P, Li Y-S, Chang Y-S, Li X-D. Anaerobic Treatment of Palm Oil Mill Effluent in Pilot-Scale Anaerobic EGSB Reactor. BioMed Research International 2015; http://dx.doi.org/10.1155/2015/398028.

[98] Yejian Z, Li Y, Lina C, Xiuhua L, Zhijian M, Zhenjia Z (2008). Startup and operation of anaerobic EGSB reactor treating palm oil mill effluent. Journal of Environmental Sciences 20: 658-663.

[99] Yejian Z, Hairen Y, Xiangyong Z, Zhenjia Z, Li Y. High-rate mesophilic anaerobic digestion of palm oil mill effluent (POME) in expanded granular sludge bed (EGSB) reactor. 
International Conference on Agricultural and Natural Resources Engineering. Advances in Biomedical Engineering 2013; 3-5: 214 - 19.

[100] Wong Y-S, Teng TT, Onga S-A, Norhashimah M, Rafatullah M, Lee H-C. Anaerobic acidogenesis biodegradation of palm oil mill effluent using Suspended Closed Anaerobic Bioreactor (SCABR) at mesophilic temperature. Procedia Environmental Sciences 2013; 18: 433 $-41$

[101] Ahmad A, Ghufran R and Wahid ZA. Effect of cod loading rate on an upflow anaerobic sludge blanket reactor during anaerobic digestion of palm oil mill effluent with butyrate. Journal of Environmental Engineering and Landscape Management 2012; 20(4); 256-64.

[102] Busu Z, Sulaiman A, Hassan MA, Shirai Y, Abd-Aziz S, Yacob S, Wakisaka M. Improved Anaerobic Treatment of Palm Oil Mill Effluent in a Semi-Commercial Closed Digester Tank with Sludge Recycling and Appropriate Feeding Strategy. Pertanika Journal of Tropical Agricultural Science, 2010; 33 (1): 27 - 37

[103] Wanitanukul S, Rukruem W and Chaiprasert P. Effect of Operating Condition on Performance of Anaerobic Hybrid Reactor at Thermophilic Temperature. Journal of Energy Technologies and Policy, 2013; 3(11): 211 - 9.

[104] Fang C, O-Thong S, Boe K, Angelidaki I. Comparison of UASB and EGSB reactors performance, for treatment of raw and deoiled palm oil mill effluent (POME). Journal of Hazardous Materials 2011; 189: 229-234.

[105] Zinatizadeh, A. A. L., Mohamed, A. R., Mashitah, M. D., Abdullah, A. Z. and Najafpour, G. D. (2006). Pretreated palm oil mill effluent (POME) digestion in an up-flow anaerobic sludge fixed film bioreactor: a comparative study. IJE Transactions B: Applications 19(1): 1 - 9.

[106] Olson ER. Influence of pH on bacterial gene expression. Molecular microbiol. 1993; 8: 5 $-14$.

[107] Stronach SM, Rudd T, Lester JN. Anaerobic digestion processes in waste water. Berlin: Springer. 1986.

[108] Zinatizadeh AAL, Mohamed AR, Abdullah AZ, Mashitah MD, Hasnain IM, Najafpour GD. Process modeling and analysis of palm oil mill effluent treatment in a up-flow anaerobic sludge fixed film bioreactor using response surface methodology (RSM). Water Research 2006; 40(17): 3193 - 208.

[109] Yu H-Q. Fang HHP, Gu G-W. Comparative performance of mesophilic and thermophilic acidogenic upflow reactor. Process Biochemistry 2002; 38: 447 - 54.

[110] Yeoh BG. Biogas projects and CDM. Environment and bioprocess technology center. SIRIM Berhad. EC-ASEAN Cogen programme phase III. (Undated). http://www.cogen3.net/presentations/asean/cdm_hcm/BiogasprojectsandCDM.pdf. Assessed march 20, 2013.

[111] Yilmaz T, Yuceer A, Basbuyuk M. A comparison of the performance of mesophilic and thermophilic anaerobic filters treating papermill wastewater. Bioresource Technology 2008; 99: $156-63$. 
[112] Kim JK, Oh BR, Chun YN, Kim SW. Effects of temperature and hydraulic retention time on anaerobic digestion of food wastes. Journal of Bioscience and Bioengineering 2006; 102: 328 -32 .

[113] Zaher, U., Li, R., Jeppsson, U., Steyer, J.P. and Chen, S. GISCOD: General integrated solid waste co-digestion model. Water Research 2009; 43: 2717 - 27.

[114] Mohan SV. Fermentative hydrogen production with simultaneous wastewater treatment: influence of pretreatment and system operating conditions. Journal of Scientific and Industrial Research 2008; 67: 950 - 61.

[115] Atif AAY, I-Razi AF, Ngan MA, Morimoto M, Iyuke S E, Veziroglu N T. Fed batch production of hydrogen from palm oil mill effluent using anaerobic microflora. International Journal of Hydrogen Energy2005; 30:1393 - 7.

[116] Vijayaraghavan K, Ahmed D. Biohydrogen generation from palm oil mill effluent using anaerobic contact filter. International Journal of Hydrogen Energy 2006; 31: 1284 - 91.

[117] Mechichi T, Sayadi S. Evaluating process imbalance of anaerobic of olive mill wastewaters, Process Biochemistry 2005; 40: 137-145.

[118] Chen Y, Cheng JJ, Creamer KS. Inhibition of anaerobic digestion process: A review. Bioresource Technology 2008; 99: $4044-64$.

[119] McCarty PL, Mosey FE. Modelling of anaerobic digestion processes. Water Science and Technology 1991; 24(8): 17-33.

[120] Paepatung N, Kullavanijava P, Loapitinun O, Songkasiri W, Nopharatana A, Chaiprasert P. Status and potential for biogas production from biomass in Thailand (2006) Final Report submitted to Joint Graduate School of Energy and Environment.

[121] Kullavanijava P, Paepatung N, Loapitinun O, Songkasiri W, Nopharatana A, Chaiprasert P, Assessment of biogas technology from biomass in Thailand (2006) Final Report submitted to Joint Graduate School of Energy and Environment.

[122] USAID. Biodigestion processes in palm oil mills. Environmental fabrics Inc. methane market. Monterrey, Mexico. 2009.

[123] Chong M-L, Rahim RA, Shirai Y, Hassan MA. Biohydrogen production by Clostridium butyricum EB6 from palm oil mill effluent. International Journal of Hydrogen Energy 2009; 34: $764-71$. 
POME

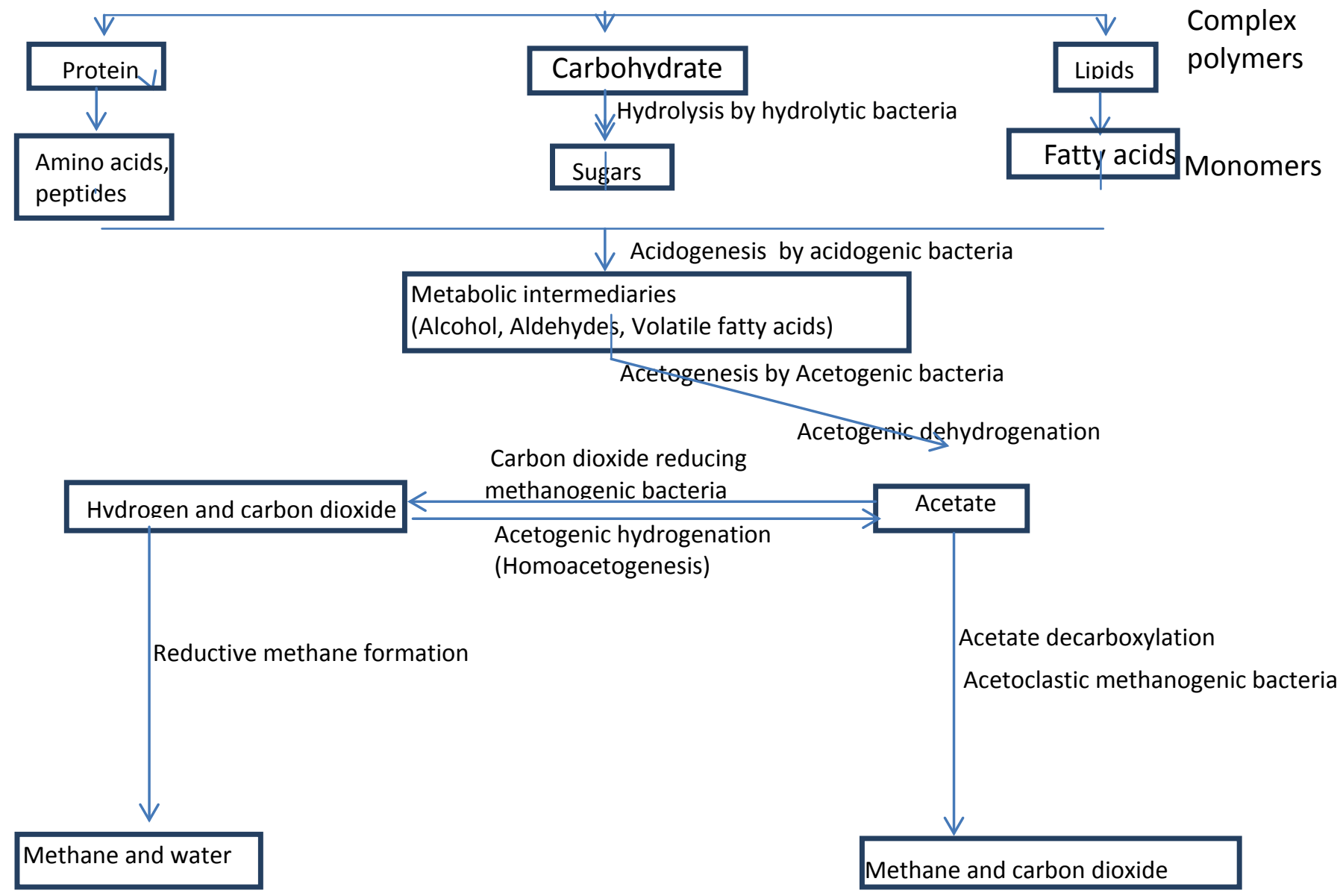

Fig 1: Processes of biogas production from anaerobic treatment of POME 
Table 1: Typical biogas composition

\begin{tabular}{|l|l|l|l|l|l|}
\hline \multirow{2}{*}{ Constituents } & \multicolumn{5}{|c|}{ \% Composition (References) } \\
\cline { 2 - 6 } & {$[34,35,41]$} & {$[42]$} & {$[20]$} & {$[43]$} & {$[1,2,9]$} \\
\hline Methane $\left(\mathrm{CH}_{4}\right)$ & $55-75$ & $50-70$ & 65 & $66-67$ & 65 \\
\hline $\begin{array}{l}\text { Carbon dioxide } \\
\left(\mathrm{CO}_{2}\right)\end{array}$ & $30-45$ & $30-40$ & 30 & 29 & 35 \\
\hline Hydrogen sulphide & $1-2$ & - & - & - & - \\
\hline Nitrogen $\left(\mathrm{N}_{2}\right)$ & $0-1$ & $1-2$ & - & $<3$ & - \\
\hline Hydrogen $\left(\mathrm{H}_{2}\right)$ & $0-1$ & $5-10$ & - & - & - \\
\hline Oxygen $\left(\mathrm{O}_{2}\right)$ & - & - & - & $<1$ & - \\
\hline
\end{tabular}

Table 2: Physicochemical parameters of palm oil milling effluents

\begin{tabular}{|c|c|c|c|c|c|c|}
\hline \multirow[t]{2}{*}{ Parameters } & \multicolumn{6}{|c|}{ References } \\
\hline & [61] & [55] & {$[27]$} & {$[60]$} & [46] & [28] \\
\hline $\mathrm{pH}$ & 5.10 & 6.56 & $5.21-6.36$ & - & 5.34 & 4.40 \\
\hline $\begin{array}{l}\text { Dissolved } \\
\text { Oxygen, mg/l }\end{array}$ & - & 4.69 & $2.57-4.13$ & - & 1.25 & - \\
\hline $\mathrm{COD}, \mathrm{mg} / \mathrm{l}$ & 821.45 & 1806.33 & $\begin{array}{ll}1231.00 & - \\
2422.00 & -\end{array}$ & $\begin{array}{l}42900.00- \\
88250.00\end{array}$ & 284.79 & 30.60 \\
\hline $\begin{array}{ll}\begin{array}{l}\text { Suspended solid } \\
\mathrm{mg} / 1\end{array} & \\
\end{array}$ & - & - & - & $14.10-26.40$ & - & 10.80 \\
\hline $\begin{array}{l}\text { Volatile } \\
\text { suspended solid } \\
\mathrm{g} / \mathrm{l}\end{array}$ & - & - & - & - & - & 8.10 \\
\hline Total solid mg/l & - & - & - & $29.60-55.40$ & 517.11 & 31.20 \\
\hline Volatile solid $\mathrm{g} / \mathrm{l}$ & & & - & - & - & 24.30 \\
\hline $\begin{array}{l}\text { Electrical } \\
\text { conductivity, } \\
\mu \mathrm{s} / \mathrm{cm}\end{array}$ & 137.34 & - & - & - & 2.51 & - \\
\hline BOD, mg/l & 502.93 & 382.93 & $\begin{array}{ll}254.00 & - \\
1541.00 & \\
\end{array}$ & $\begin{array}{l}17000.00 \\
26700.00 \\
\end{array}$ & 123.68 & - \\
\hline $\mathrm{SO}_{4}, \mathrm{mg} / \mathrm{l}$ & - & - & - & - & 65.75 & 60.00 \\
\hline $\mathrm{NO}_{3}, \mathrm{mg} / \mathrm{l}$ & - & - & - & - & 262.26 & - \\
\hline $\mathrm{K}, \mathrm{mg} / \mathrm{l}$ & - & 19.64 & $9.53-29.14$ & $\begin{array}{l}1281.00 \\
1928.00 \\
\end{array}$ & 295.74 & 510.00 \\
\hline $\mathrm{Mg}, \mathrm{mg} / \mathrm{l}$ & 193.50 & - & - & $\begin{array}{ll}254.00 & - \\
344.00 & -\end{array}$ & 283.46 & 170.00 \\
\hline $\mathrm{Na}, \mathrm{mg} / \mathrm{l}$ & 225.50 & - & - & - & 332.26 & 4.00 \\
\hline $\mathrm{Ca}, \mathrm{mg} / \mathrm{l}$ & 605.50 & - & - & $\begin{array}{ll}276.00 & - \\
405.00\end{array}$ & 252.41 & 220.00 \\
\hline $\mathrm{Al}, \mathrm{mg} / \mathrm{l}$ & - & - & - & - & - & 120.00 \\
\hline $\mathrm{B}, \mathrm{mg} / \mathrm{l}$ & - & - & - & - & - & 0.90 \\
\hline $\mathrm{N}, \mathrm{mg} / \mathrm{l}$ & 3.24 & 12.87 & $7.55-20.65$ & - & - & 365.00 \\
\hline $\mathrm{P}, \mathrm{mg} / \mathrm{l}$ & 17.80 & 8.18 & $5.26-8.68$ & - & 165.65 & 110.00 \\
\hline
\end{tabular}




\begin{tabular}{|c|c|c|c|c|c|c|}
\hline $\mathrm{Cd}, \mathrm{mg} / \mathrm{l}$ & - & 0.03 & $0.01-0.02$ & $0.01-0.02$ & - & - \\
\hline $\mathrm{Cu}, \mathrm{mg} / \mathrm{l}$ & - & 2.44 & $0.60-1.61$ & $0.80-1.60$ & - & 1.00 \\
\hline $\mathrm{Fe}, \mathrm{mg} / \mathrm{l}$ & - & 5.62 & $1.81-13.81$ & $\begin{array}{l}75.00 \\
164.00\end{array}$ & 183.49 & 205.00 \\
\hline $\mathrm{Cr}, \mathrm{mg} / \mathrm{l}$ & - & 2.01 & $0.61-1.68$ & $0.05-0.43$ & - & - \\
\hline $\mathrm{Zn}, \mathrm{mg} / \mathrm{l}$ & - & - & - & $1.20-1.80$ & 120.95 & 6.00 \\
\hline Mo, mg/l & - & - & - & - & - & 0.10 \\
\hline $\mathrm{Mn}, \mathrm{mg} / \mathrm{l}$ & - & - & - & $2.10-4.40$ & 34.25 & 0.60 \\
\hline $\mathrm{Ni}, \mathrm{mg} / \mathrm{l}$ & - & - & - & - & - & 1.20 \\
\hline $\mathrm{Si}, \mathrm{mg} / \mathrm{l}$ & - & - & - & - & - & 55.00 \\
\hline $\mathrm{Ba}, \mathrm{mg} / \mathrm{l}$ & - & - & - & - & - & 0.30 \\
\hline Co, mg/l & - & - & - & $0.04-0.06$ & - & 0.01 \\
\hline
\end{tabular}

Table 3: Microbial species isolated from POME, which may be involved in the decomposition process.

\begin{tabular}{|c|c|c|c|c|c|c|}
\hline \multirow{2}{*}{$\begin{array}{l}\text { Microbial } \\
\text { class }\end{array}$} & \multirow{2}{*}{$\begin{array}{l}\text { Microbial } \\
\text { groups }\end{array}$} & \multicolumn{5}{|l|}{ Microorganisms } \\
\hline & & [61] & {$[55]$} & {$[66]$} & {$[67]$} & {$[68,69]$} \\
\hline \multirow{11}{*}{ Fungi } & \multirow{11}{*}{-} & Aspergillus niger & $\begin{array}{l}\text { Aspergillus } \\
\text { niger, } \\
\text { funmigatus }\end{array}$ & $\begin{array}{l}\text { Aspergillus } \\
\text { niger, A. flavus, } \\
\text { A. ochraceous }\end{array}$ & Aspergillus flavus & $\begin{array}{l}\text { Aspergillus niger, } \\
\text { A.flavus }\end{array}$ \\
\hline & & $\begin{array}{l}\text { Penicillium } \\
\text { species }\end{array}$ & $\begin{array}{l}\text { Penicillium } \\
\text { species }\end{array}$ & $\begin{array}{l}\text { Penicillium } \\
\text { species }\end{array}$ & $\begin{array}{l}\text { Penicillium } \\
\text { species }\end{array}$ & Penicillium species. \\
\hline & & - & - & - & $\begin{array}{l}\text { Trichoderma } \\
\text { viride }\end{array}$ & - \\
\hline & & - & - & - & $\begin{array}{l}\text { Botryodiplodia } \\
\text { theobromae }\end{array}$ & - \\
\hline & & - & Mucor species & Mucor species & $\begin{array}{l}\text { Cunninghamella } \\
\text { echinulata }\end{array}$ & - \\
\hline & & $\begin{array}{l}\text { Geotrichum } \\
\text { candidum }\end{array}$ & - & - & $\begin{array}{l}\text { Geotrichum } \\
\text { candidum }\end{array}$ & - \\
\hline & & - & $\begin{array}{l}\text { Fusarium } \\
\text { species }\end{array}$ & $\begin{array}{l}\text { Fusarium } \\
\text { species }\end{array}$ & $\begin{array}{l}\text { Fusarium } \\
\text { moniliforme }\end{array}$ & - \\
\hline & & - & - & - & - & $\begin{array}{l}\text { Saccharomyces } \\
\text { cerevisiae }\end{array}$ \\
\hline & & - & - & - & - & Yarrowia lipolytica \\
\hline & & - & - & - & - & $\begin{array}{l}\text { Clavispora } \\
\text { lusitaneae }\end{array}$ \\
\hline & & Candida species & $\begin{array}{l}\text { Candida } \\
\text { species }\end{array}$ & - & - & $\begin{array}{l}\text { Candida } \\
\text { intermedia, } \\
\text { tropicalis }\end{array}$ \\
\hline \multirow{5}{*}{ Bacteria } & \multirow{5}{*}{$\begin{array}{l}\text { Acid } \\
\text { formers; } \\
\text { hydrocarbon } \\
\text { degraders }\end{array}$} & $\begin{array}{l}\text { Pseudomonas } \\
\text { species }\end{array}$ & $\begin{array}{l}\text { Pseudomonas } \\
\text { species }\end{array}$ & $\begin{array}{l}\text { Pseudomonas } \\
\text { species }\end{array}$ & $\begin{array}{l}\text { Pseudomonas } \\
\text { species }\end{array}$ & - \\
\hline & & Bacillus species & $\begin{array}{l}\text { Bacillus } \\
\text { species }\end{array}$ & Bacillus species & Bacillus species & $\begin{array}{l}\text { Bacillus carotarum, } \\
\text { B. lentus, B. } \\
\text { pumilis, } \\
\text { stearothermophilus, }\end{array}$ \\
\hline & & - & $\begin{array}{l}\text { Staphylococcus } \\
\text { aureus }\end{array}$ & $\begin{array}{l}\text { Staphylococcus } \\
\text { species }\end{array}$ & Esherichia coli & - \\
\hline & & $\begin{array}{l}\text { Corynebacterium } \\
\text { species. }\end{array}$ & - & $\begin{array}{l}\text { Corynebacterium } \\
\text { species. }\end{array}$ & $\begin{array}{l}\text { Clostridium } \\
\text { species }\end{array}$ & - \\
\hline & & - & - & Serratia species & Flavobacterium & - \\
\hline
\end{tabular}




\begin{tabular}{|l|l|l|l|l|l|l|}
\hline & & - & - & - & Desulfovibrio & - \\
\cline { 3 - 7 } & $\begin{array}{l}\text { Micrococcus } \\
\text { species }\end{array}$ & $\begin{array}{l}\text { Micrococcus } \\
\text { species }\end{array}$ & - & Microcococcus & Micrococcus luteus \\
\cline { 2 - 7 } & $\begin{array}{l}\text { Methane } \\
\text { formers }\end{array}$ & - & - & - & $\begin{array}{l}\text { Methanococcus } \\
\text { species }\end{array}$ & - \\
\cline { 2 - 7 } & - & - & - & Methanobacterium & - \\
\hline
\end{tabular}

Table 4: Microorganisms involved in microbial conversion of wastes to biogas

\begin{tabular}{|c|c|c|c|c|c|}
\hline $\begin{array}{l}\text { Microbiological } \\
\text { pathways }\end{array}$ & Microbial class & Substrate/products & $\begin{array}{l}\text { Conversion } \\
\text { process }\end{array}$ & Examples & References \\
\hline \multirow[t]{3}{*}{ Hydrolysis } & \multirow[t]{3}{*}{$\begin{array}{l}\text { Hydrolytic } \\
\text { bacteria }\end{array}$} & $\begin{array}{l}\text { Complex polymer } \\
\text { to monomers }\end{array}$ & $\begin{array}{l}\text { Proteins to its } \\
\text { lower forms viz. } \\
\text { amino acid and } \\
\text { peptides }\end{array}$ & $\begin{array}{lr}\text { Some species of } \\
\text { Clostridium and } \\
\text { Bacillus }\end{array}$ & {$[1,9,62,70]$} \\
\hline & & $\begin{array}{l}\text { Complex polymer } \\
\text { to monomers }\end{array}$ & $\begin{array}{l}\text { Carbohydrate to } \\
\text { its } \quad \text { lower } \\
\text { products } \\
\text { sugar }\end{array}$ & $\begin{array}{lr}\text { Some species } & \text { of } \\
\text { Clostridium and } \\
\text { Staphylococcus }\end{array}$ & {$[9,7062,70]$} \\
\hline & & $\begin{array}{l}\text { Complex polymer } \\
\text { to monomers }\end{array}$ & $\begin{array}{l}\text { Lipids to its } \\
\text { lower fatty acid, } \\
\text { constituents } \\
\text { and alcohol etc }\end{array}$ & $\begin{array}{l}\text { Some species of } \\
\text { Clostridium } \\
\text { Staphylococcus }\end{array}$ & {$[1,9,62,70]$} \\
\hline \multirow[t]{2}{*}{ Acidogenesis } & \multirow[t]{2}{*}{$\begin{array}{l}\text { Acidogenic } \\
\text { fermentative } \\
\text { bacteria }\end{array}$} & $\begin{array}{l}\text { Monomers to } \\
\text { intermediaries } \\
\text { product }\end{array}$ & $\begin{array}{l}\text { Amino acids are } \\
\text { converted to } \\
\text { fatty acids, } \\
\text { acetate }\end{array}$ & $\begin{array}{l}\text { E. coli, Some species } \\
\text { of Staphylococcus, } \\
\text { Pseudomonas, } \\
\text { Bacillus, Desulfovibio }\end{array}$ & {$[1,9,62,70]$} \\
\hline & & $\begin{array}{ll}\text { Monomers } & \text { to } \\
\text { intermediaries } & \\
\text { product } & \end{array}$ & $\begin{array}{l}\text { Sugar to lower } \\
\text { metabolites }\end{array}$ & $\begin{array}{l}\text { Some species of } \\
\text { Clostridium }\end{array}$ & {$[9,62,70]$} \\
\hline \multirow[t]{2}{*}{ Acetogenesis } & \multirow[t]{2}{*}{$\begin{array}{l}\text { Acetogenesis } \\
\text { bacteria }\end{array}$} & $\begin{array}{l}\text { Metabolic } \\
\text { intermediaries to } \\
\text { methane, carbon } \\
\text { dioxide, acetate } \\
\text { etc }\end{array}$ & $\begin{array}{ll}\text { Fatty acid } & \text { or } \\
\text { alcohol } & \text { to } \\
\text { hydrogen } & \text { or } \\
\text { acetate } & \end{array}$ & Clostridium species & {$[9,62,70]$} \\
\hline & & $\begin{array}{l}\text { Metabolic } \\
\text { intermediaries to } \\
\text { methane, carbon } \\
\text { dioxide, acetate } \\
\text { etc }\end{array}$ & $\begin{array}{ll}\begin{array}{l}\text { Fatty acid } \\
\text { alcohol }\end{array} & \begin{array}{l}\text { or } \\
\text { to }\end{array} \\
\text { hydrogen } & \text { or } \\
\text { acetate } & \end{array}$ & $\begin{array}{l}\text { Sytrophomonas } \\
\text { species }\end{array}$ & {$[9,62,70]$} \\
\hline \multirow[t]{2}{*}{ Methanogenesis } & $\begin{array}{l}\mathrm{CO}_{2} \text { reducing } \\
\text { methanogens }\end{array}$ & $\begin{array}{l}\text { Methane, carbon } \\
\text { dioxide, acetate } \\
\text { etc to methane, } \\
\text { carbon dioxide, } \\
\text { hydrogen }\end{array}$ & $\begin{array}{l}\text { Hydrogen and } \\
\mathrm{CO}_{2} \text { to methane }\end{array}$ & $\begin{array}{l}\text { Methanobacterium, } \\
\text { methanoplanus }\end{array}$ & {$[9,62,70]$} \\
\hline & $\begin{array}{l}\text { Aceticlastic } \\
\text { methanogens }\end{array}$ & $\begin{array}{l}\text { Methane, carbon } \\
\text { dioxide, acetate } \\
\text { etc to methane, } \\
\text { carbon dioxide }\end{array}$ & $\begin{array}{l}\text { Acetate to } \\
\text { methane and } \\
\mathrm{CO}_{2}\end{array}$ & $\begin{array}{l}\text { Metahnobacteria } \\
\text { (methanococcus) }\end{array}$ & {$[9,62,70]$} \\
\hline
\end{tabular}

Table 5: Methane composition during anaerobic treatment of POME with their OLR and HRT 


\begin{tabular}{|c|c|c|c|c|c|}
\hline Configurators & $\begin{array}{l}\text { Methane } \\
\text { composition, \% }\end{array}$ & $\begin{array}{l}\text { Organic loading } \\
\text { rates }(\mathrm{kg} \\
\left.\mathrm{COD} / \mathrm{m}^{3} \text { day }\right)\end{array}$ & $\begin{array}{l}\text { Hydraulic } \\
\text { retention time } \\
\text { (days) }\end{array}$ & $\begin{array}{l}\text { COD removal } \\
\text { efficiency, } \%\end{array}$ & References \\
\hline \multirow[t]{6}{*}{ EGSB } & 70 & $1.45-17.5$ & 2 & 91 & [98] \\
\hline & 70 & $1.45-16.5$ & 3 & 90.5 & [99] \\
\hline & 51 & $\begin{array}{lll}2 & \text { gVSK } & - \\
\text { reactor.day }\end{array}$ & 10 & 96.5 & \multirow[t]{6}{*}[104]{} \\
\hline & 61 & $\begin{array}{l}2.9 \text { gVSK }- \\
\text { reactor.day }\end{array}$ & 5 & 95.5 & \\
\hline & 60 & $\begin{array}{lll}5.8 & \text { gVSK } & - \\
\text { reactor.day } & \end{array}$ & 5 & 92.5 & \\
\hline & 59 & $\begin{array}{l}10.4 \mathrm{gVSK} \\
\text { reactor.day }\end{array}$ & 5 & 65 & \\
\hline \multirow[t]{2}{*}{$\mathrm{EGSB}^{\mathrm{c}}$} & 70 & $\begin{array}{l}1.3 \mathrm{gVSK}- \\
\text { reactor.day }\end{array}$ & 5 & 94 & \\
\hline & 73 & $\begin{array}{l}2.6 \quad \mathrm{gVSK} \\
\text { reactor.day }\end{array}$ & 5 & 91.5 & \\
\hline \multirow{4}{*}{$\begin{array}{l}\text { Anaerobic } \\
\text { digester }\end{array}$} & 70.03 & 2.43 & 14 & 70 & \multirow[t]{4}{*}[36]{} \\
\hline & 69.29 & 5.09 & 10 & 68 & \\
\hline & 66.83 & 6.50 & 7 & 65 & \\
\hline & 66.41 & 8.70 & 6.5 & 65 & \\
\hline Anaerobic pond & 54.4 & 1.4 & 40 & 97.8 & [75] \\
\hline \multirow[t]{6}{*}{ MAS } & 74.2 & 2 & 400.6 & 96.5 & \multirow[t]{6}{*}{ [93] } \\
\hline & 72.6 & 5 & 63.6 & 96.0 & \\
\hline & 69.7 & 7 & 20.4 & 95.8 & \\
\hline & 70.8 & 9 & 11.6 & 95.4 & \\
\hline & 69.1 & 11 & 8.86 & 94.9 & \\
\hline & 65.7 & 13 & 5.70 & 94.8 & \\
\hline \multirow[t]{6}{*}{ UAMAS } & 77 & 16 & 0.5 & 98.7 & \multirow[t]{6}{*}{ [95] } \\
\hline & 74 & 12 & 2.0 & 97.0 & \\
\hline & 71.8 & 8 & 4 & 96.0 & \\
\hline & 68.4 & 6 & 11.0 & 93.0 & \\
\hline & 73.0 & 5 & 13.0 & 95.0 & \\
\hline & 67.8 & 4 & 15.0 & 93.0 & \\
\hline \multirow[t]{6}{*}{ UMAS } & 79 & 0.5 & 480.3 & 98.5 & \multirow[t]{6}{*}{ [96] } \\
\hline & 75.5 & 1.5 & 76.40 & 97.5 & \\
\hline & 70.2 & 3 & 20.3 & 98.0 & \\
\hline & 71.8 & 5.5 & 8.78 & 97.7 & \\
\hline & 70.6 & 8.5 & 7.36 & 97.6 & \\
\hline & 68.5 & 9.5 & 5.40 & 96.7 & \\
\hline $\mathrm{UASFF}^{\mathrm{a}}$ & $51.33-84.4$ & \multirow{2}{*}{$\begin{array}{l}3.8 \\
29 \mathrm{~g} / \mathrm{COD} / 1 . \mathrm{d}\end{array}$} & - & $82.7-97.3$ & \multirow[t]{2}{*}[105]{} \\
\hline $\mathrm{UASFF}^{\mathrm{b}}$ & $30.96-82.61$ & & - & $62.2-96.7$ & \\
\hline UASFF & 71.9 & 11.58 & 3 & 97 & [89] \\
\hline \multirow[t]{4}{*}{ CSTR } & 67 & - & 4 & - & \multirow[t]{3}{*}{ [87] } \\
\hline & 66 & - & 6 & - & \\
\hline & 64 & - & 8 & - & \\
\hline & 62.5 & 3.33 & 18 & 80 & [93] \\
\hline UASB & 54.2 & 10.63 & 4 & 98.4 & [65] \\
\hline \multirow[t]{3}{*}{ UASB } & 55 & $\begin{array}{ll}2 & \mathrm{gVSK} \\
\text { reactor.day } & -\end{array}$ & 10 & 96.5 & \multirow[t]{3}{*}[104]{} \\
\hline & 66 & $\begin{array}{l}2.9 \text { gVSK } \\
\text { reactor.day }\end{array}$ & 5 & 95.5 & \\
\hline & 61 & $\begin{array}{ll}5.8 & \text { gVSK }\end{array}$ & 5 & 92.5 & \\
\hline
\end{tabular}




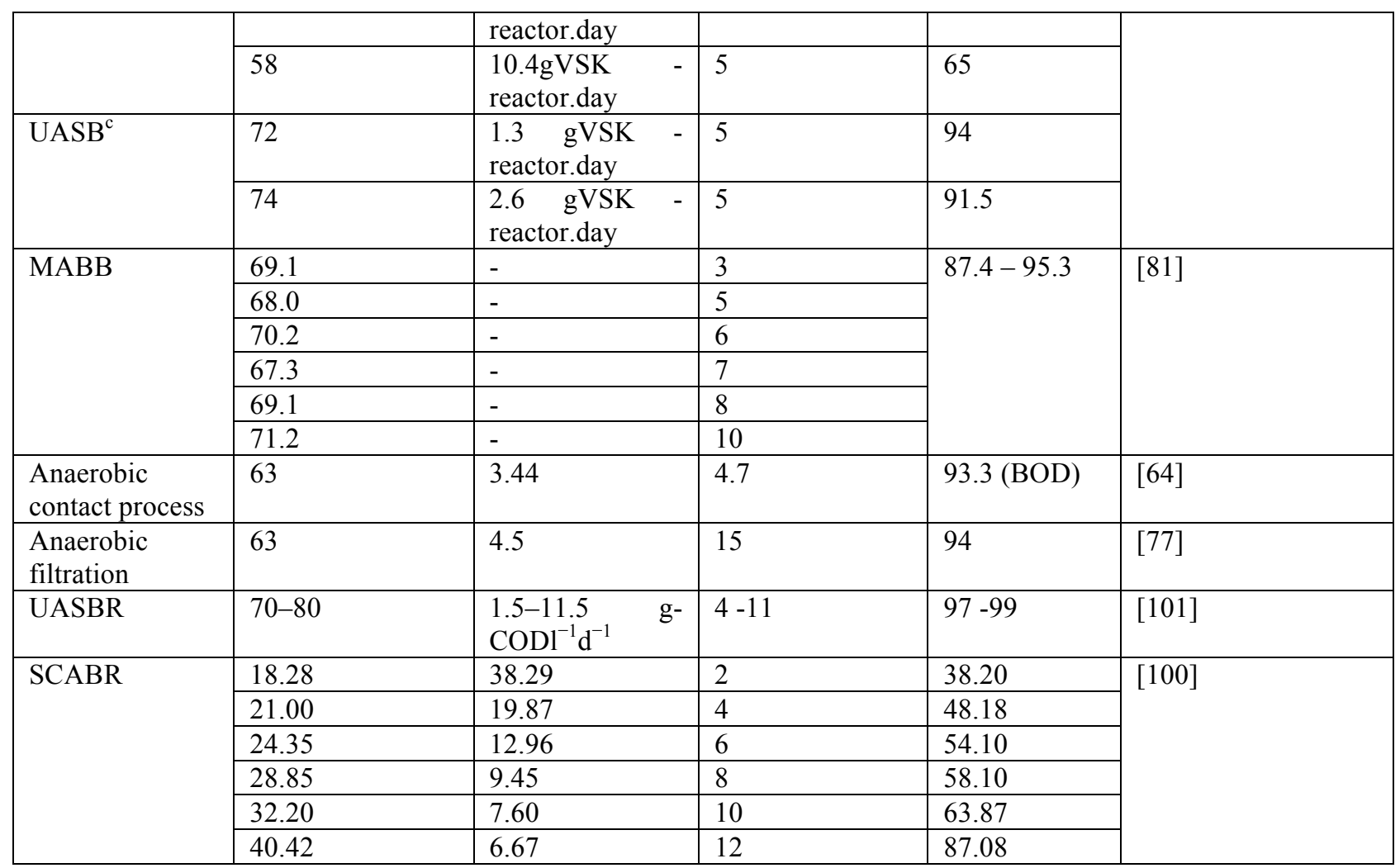

$\mathrm{a}=$ presettled POME, $\mathrm{b}=$ chemically pretreated POME (coagulation and flocculation), $\mathrm{c}=$ deoiled POME 